\title{
Conceptual Analysis of Derivative as a Rate of Change and Analysis of the Mathematics Textbooks
}

\author{
Mahmut KERTİL*
}

\begin{abstract}
In this study, initially, we provided a conceptual analysis for the rate of change interpretation of derivative from the quantitative reasoning perspective. Then, based upon the principles drawn from the quantitative reasoning perspective, the 12th-grade Turkish mathematics textbooks were analyzed, specifically focusing on the derivative topic, using the document analysis research method. The findigs indicated that mathematics textbooks are insufficient in terms of the diversity of real-life contexts. Even, the derivative as a rate of change concept is generally introduced limited with the kinematic contexts. Units of the quantities are properly used in the real-life contexts that appeared in the textbooks, however, the discussions and interpretations on the derivative concept by using the units of the quantities are not deep enough. Moreover, the covariation and relative-size ideas that are accepted to be prominent for the understanding of the rate of change are not sufficiently emphasized in all of the textbooks. The weak points in the Turkish mathematics textbooks that need to be enriched related to the concept of the derivative as a rate of change were emphasized. In the light of the findings, we also discussed the aspects that need to be developed in the textbooks provided with some samples of the real-life interpretations of the derivative as a rate of change and as relative size.
\end{abstract}

Keywords: Covariation, derivative, mathematics textbooks, quantitative reasoning, rate of change.

\footnotetext{
* Orcid ID: https://orcid.org/0000-0002-0633-7144, Dr. Marmara University, Turkey,
} mkertil@marmara.edu.tr 


\section{INTRODUCTION}

The derivative is one of the basic concepts of calculus and it requires a robust understanding of some of the former concepts such as rate, ratio, limit, and slope. Although the rate of change is the most extensive real-life interpretation of the derivative, students and teachers have difficulties conceptualizing it (Bezuidenhout, 1998; Byerley \& Thompson, 2017; Byerley, 2019; Bingolbali, 2008; Herbert \& Pierce, 2011,2012 ). Weakness or inadequacy of the textbooks is one of the possible reasons for student and teacher difficulties with the rate of change interpretation of derivative (Bingolbali, 2008; Byerley \& Thompson, 2017; Mkhatshwa, 2016; Mkhatshwa \& Doerr, 2018; Teuscher \& Reys, 2012).

As one of the most important guides for teacher practices and as they involve an interpretation of curricula, mathematics textbooks have been the focus of various research studies (Bingolbali \& Bingolbali, 2020; Howson, 2013; Schmidt, 2012; Yavuz \& Baştürk, 2011). Studies on mathematics textbooks generally focus on analyzing (i) the mathematical topics covered, (ii) students' performance expectations (i.e., problem solving, using routine or non-routine procedures), (iii) visual features (e.g., use of different representations), and (iv) international comparative studies (Howson, 2013). Comparison of the mathematics textbooks for different nations are commonly appearing studies maybe because of the didactic outcomes obtained from different customs and perspectives that different countries have (e.g., İncikabı \& Tjoe, 2013; Yavuz \& Baştürk, 2011). We also observe many studies focusing on the coverage of a particular concept in textbooks, the nature of the problems and activities used, or the use of multiple representations (e.g., Bingolbali \& Bingolbali, 2020; Yavuz v\& Baştürk, 2011). Although there are some textbook analysis studies for the entire topic of derivative (e.g., de Almeida \& da Silva, 2018; Park, 2016; Randhal \& Grevholm, 2010, there is no research study focusing on the rate of change interpretation of it in particular. In the study by Randahl and Grandholm (2010), for instance, it is reported that calculus textbooks used in engineering faculty classes covered the derivative concept with an emphasis on procedural aspects rather than conceptual knowledge.

As mathematics textbooks have been seemed to be one of the main reasons for student and teacher difficulties with the concept of rate of change, and because of the inadequacy of national and international studies focusing on the rate of change in textbooks, in particular, it worth researching Turkish mathematics textbooks (Bingolbali, 2008). The findings of this study may guide educators and textbook writers to write more eligible mathematics textbooks. In this study, at first, we provided a conceptual analysis of the rate of change from the perspective of Thompson's (1994; 2011) quantitative reasoning theory. From this conceptual analysis, the important points and basic principles were determined that should be considered in the teaching and learning of the derivative as a rate of change. And then, by using the principles derived from the conceptual analysis, we analyzed a total of 3 mathematics textbooks, limited with the derivative topic, which have been approved by the Board of Education (TTKB) and are still being thought in all kinds of high schools following the Ministry of 
Education (MEB) curricula. The following research questions guided the textbook analysis side of this study:

- How was the rate of change interpretation of the derivative covered in mathematics textbooks?

- What kind of real-life contexts has been included in the mathematics textbooks regarding the derivative as a rate of change?

- How (or to what extent) the covariation and relative-size ideas involved in the rate of change were emphasized in the mathematics textbooks?

\section{A CONCEPTUAL ANALYSIS ON RATE OF CHANGE}

The meaning of derivative can be represented or interpreted as (i) slope of tangent line, (ii) rate of change, (iii) difference quotient with limiting ( $\lim _{h \rightarrow 0} \frac{f(x+h)-f(x)}{h}$ ), and (iv) velocity with different process-object layers (Zandieh, 2000; Zandieh \& Knapp, 2006). One or a few of these interpretations come into prominence according to the context that a problem or task was presented (Weber \& Dorko, 2014). For example, the slope of a tangent line or different quotient interpretations will be at the forefront when a task is given with a graphical representation, while speed interpretation will be apparent in a kinematics context. In this section, the meaning of derivative as a rate of change will be explained. We will try to describe what it means a robust conception of the rate of change from the quantitative reasoning perspective (Thompson, 1994; 2011).

\section{Rate of Change Concept from the Quantitative Reasoning Perspective}

Quantitative reasoning is a theory introduced by Thompson (1994; 2011) which analyzes and explains in-depth meanings of mathematical ideas and concepts in real-life contexts. From the quantitative reasoning perspective, giving meaning to a mathematical idea in a real-life context can be verified after conceiving it as a quantity that schematically involves (i) the existence of an object, (ii) an attribute or quality of the object, (iii) an appropriate unit, and (iii) quantification of the attribute (Thompson, 1994). Let's think about a moving vehicle. The vehicle here is an object. The moving nature is its attribute or quality. As the moving nature of the vehicle is conceived as a quality, quantifying it by assigning a numerical value and with an appropriate unit comes into mind, and to do this we need mathematical operations. In this example, we quantify velocity (the quality of the vehicle) by using the division operation in the form of a difference quotient.

Rate of change, from the quantitative reasoning perspective, has been described as " $a$ new quantity obtained as the result of multiplicative comparison of changes in two other quantities" and this is called a quantitative operation (Thompson, 2011, p.17). Multiplicative comparison is a quantitative operation for which the division is used as a 
numerical (arithmetical) operation. Using the division arithmetic operation does not make the rate of change concept simple, because thousands of real-life contexts can be found in which division operation can be utilized. The main difficulty here is conceiving the rate of change as a quantitative operation of "the multiplicative comparison of the changes (relative-size) in two simultaneously changing quantities" and then selecting the true arithmetical operation for this. Because the rate of change is a new quantity obtained as a result of a multiplicative comparison of the changes in two other quantities, it is an abstract and intensive quantity (Schwartz, 1988). Quantification of the rate of change involves an indirect measurement as it involves the ratio of the changes in two other quantities (Quantity-1, Quantity-2) that changes together (Stroup, 2002; Thompson, 1994). For conceiving the rate of change as a new quantity, there is a need for a holistic view about two simultaneously changing quantities and the new quantity obtained from them $\left(x, y, \frac{\Delta y}{\Delta x}\right)$ as a quantitative structure (Thompson, 2011). Reconsidering the speed concept in the previous example, it is a new and abstract quantity obtained by using distance and time quantities, so a quantitative structure is needed (Distance, Time, Distance/time) for a clear understanding of speed (Thompson, 2011). Therefore, a robust conception of derivative as a rate of change requires an interpretation of it as a measure of relative size in the changes of two quantities (Byerley \& Thompson, 2017). Relative-size here stands for the third (new and abstract) quantity obtained as a result of the multiplicative comparison of two quantities. Rate of change as relative-size means that any sized change in the independent variable will result in a change in the dependent variable as how many times as much.

For instance, let's assume $V(h)=5 h^{2}$ is an algebraic representation giving the amount of water (lt) as a function of its height (m) in a pot. We will get $V(2)=20(\mathrm{lt})$ and $V^{l}(h)=10 h \Rightarrow V^{l}(2)=20 \quad(\mathrm{lt} / \mathrm{m})$ values. The meaning of $V^{l}(2)=20(\mathrm{lt} / \mathrm{m})$ expression as a relative size is that any sized change in height at the instant of $h=2 \mathrm{~m}$ will result in 20 times as much change in the volume. In other words, at the instant of $h=2 \mathrm{~m}$, if the height change (increase) by $0,03 \mathrm{~m}$, the volume will change (increase) by $0,6 \mathrm{lt}$ that indicates the expression of $V(2,03) \approx 20,6$. The expression $V(2,03) \approx 20,6$ should be interpreted as an approximate value of volume at $h=2 \mathrm{~m}$ because the instantaneous rate of change is valid for infinitesimal changes and a change of $0,03 \mathrm{~m}$ is a very big value when compared to an infinitesimal amount of change. Another example with the same function is provided in Figure-1 below. 


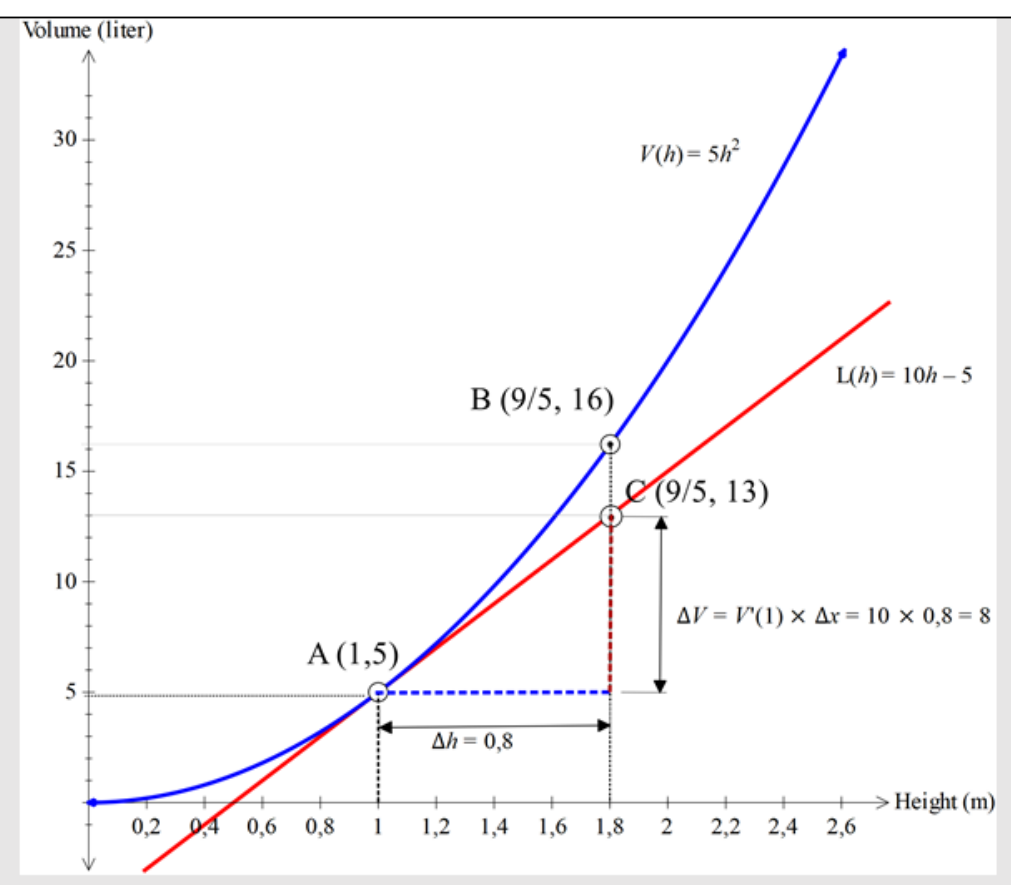

\section{Relative size:}

$$
\begin{aligned}
& \frac{\Delta V}{\Delta h}=m \Rightarrow \Delta V=m \cdot \Delta h \\
& \frac{d V}{d h}=m \Rightarrow d V=m \cdot d h
\end{aligned}
$$

The $V^{i}(1)=10$ (liter $\left./ \mathrm{m}\right)$ expression means, at the instant of $\mathrm{h}=1$ meter, any sized change in $h$ will result in 10 times as much change in volume. For example, as $h$ variable increased by 0,8 meter, $V$ variable will change (increase) 10 times as much of this ( 8 liter). At that point, we get the expression $V(1+0,8) \approx 5+8=13$ liter.

The real value of the function at this point is $V(1,8)=16$ liter as can be seen on the graph.

Figure 1. The meaning of rate of change as a relative size

It should be noted here that the difference quotient in the above examples can be interpreted as an example of an average rate of change because 0,03 or 0,8 meters are big values of change when compared to an infinitesimal change. Additionally, the above examples show that the derivative value at a particular point can be used to guess the approximate value of the function around the given point which is covered with the "linear approximation" topic in calculus textbooks (see Figure 2). 
Linear Approximation: $L(x) \approx f\left(x_{0}\right)+f^{l}\left(x_{0}\right) \cdot\left(x-x_{0}\right)=f\left(x_{0}\right)+f^{l}\left(x_{0}\right) \cdot \Delta x$

We know that the derivative of $V(h)=5 h^{2}$ function at the point $h=1$ is $V^{l}(1)=10$. The equation tangent line drawn at that point is;

$$
L(h)=10 h-5
$$

$L(h)$ is the linear approximation function that can be used to calculate the approximate values of $V(h)$ around $h=1$.

For example, the approximate value of $V(1+0,8)=V(1,8)$ can be calculated by using $L(h)$ as follows:

$$
\begin{gathered}
L(h) \approx V\left(h_{0}\right)+V^{l}\left(h_{0}\right) \cdot \Delta h \\
L(1+0,8)=V(1)+V^{l}(1) \cdot 0,8 \\
L(1,8) \approx V(1,8) \approx 5+10 \cdot 0,8=13
\end{gathered}
$$

Figure 2. Relating the relative size interpretation of derivative with linear approximation

The interpretations of derivative (or rate of change) in economic contexts as a marginal cost (change in total cost for producing one additional product) or marginal revenue are examples of the linear approximation idea and so they involve margin of errors. Some verbal expressions used for interpreting derivative as a rate of change like "change in volume per unit height" or "speed is the distance covered per unit time" also involve relative-size idea, but they form a special case of relative size as the change in the independent variable is fixed to one unit. Therefore, although verbal expressions like "change in volume per unit height" are powerful ideas for the rate of change, because of a chunky way of thinking they may result in the misconception that rate of change is an amount of change in the dependent variable (Cooney et al., 2010).

\section{Why is covariational reasoning important?}

Many research studies reported the need for covariational reasoning ability for conceptual understanding of derivative as a rate of change, difference quotient, slope, speed, or relative size (e.g., Carlson et al., 2002; Confrey \& Smith, 1994; Kertil, 2020; Thompson, 1994; Thompson \& Carlson, 2017). Covariational reasoning entails being able to see and coordinate the changes in two simultaneously changing quantities at the same time. In the study by Kertil and colleagues (2019), it is reported a bidirectional relationship between covariational reasoning ability and a robust conception of the rate of change. Besides, many studies reported a lack of covariational reasoning abilities as being one of the main sources of student and teacher difficulties with the concept of rate of change (Byerley \& Thompson, 2017; Thompson, 1994; Thompson et al., 2017; Zandieh \& Knapp, 2006).

According to the updated version of the covariational reasoning framework by Thompson and Carlson (2017), the upper levels of covariational reasoning have been labeled as chunky continuous covariation and smooth continuous covariation respectively. Chunky continuous covariation indicates an emphasis on the discrete nature of the changes in the independent variable, while smooth continuous covariation indicates focusing on the dynamic and continuous changes without a need for dividing into intervals. As an example, for a vehicle with a $100 \mathrm{~km} /$ hour speed, thinking the 
distance covered for every 1 hour will be $100 \mathrm{~km}$, or for every 2 hours the distance will be $200 \mathrm{~km}$ is an example of a chunky way of covariational reasoning. For the same situation, thinking the speed of the vehicle in a way that for any sized time interval (e.g., for every 0,005 seconds or for every 2 minutes), change in the distance will differ, but the speed as a rate of change will remain constant indicating a relative size between changes in two quantities involves a smooth continuous covariational reasoning. Moreover, in a volume-height context, for example, the interpretation that "change in volume per unit volume" involves a chunky way of covariational reasoning in nature as the changes in height is fixed to 1 unit. Smooth continuous covariational reasoning requires being able to see the rate of change as relative size (the volume will change as $\mathrm{x}$ (relative size) times as much for any sized change in height). Therefore, for a robust conception of the derivative as a rate of change, high levels of covariational reasoning abilities are required.

To sum up, to foster students' understanding of the derivative as a rate of change and as a new quantity, the theory of quantitative reasoning points out the necessity of emphasizing the quantities involved in the derivative as a rate of change across different real-life contexts. To do this, the first issue that should be considered is the diversity of real-life contexts (Byerley \& Thompson, 2017; Jones, 2017; Mkhatshwa, 2018). Secondly, the use of quantities with their units and in-depth interpretations of them are required (Thompson, 1994). And thirdly, to foster students developing the idea of the rate of change as a new and abstract quantity obtained from the quantities that change together, there is a need for an emphasis on covariational reasoning and the idea of relative size (Byerley \& Thompson, 2017).

\section{TEACHING AND LEARNING OF RATE OF CHANGE: LITERATURE REVIEW}

The review of the literature shows some major problems with the understanding of the rate of change, and some common student and teacher difficulties have been reported in giving meaning to the rate of change in different real-life contexts (Byerley, 2019; Byerley \& Thompson, 2017; Gravemeijer \& Doorman, 1999; Herbert \& Pierce, 2012; Mkhatshwa, 2016; Mkhatshwa \& Doerr, 2018). Conceiving rate of change as an amount of change in one quantity is one of the most frequently reported findings in the literature (Byerley \& Thompson, 2017; Jones, 2017; Kertil, 2014; Lobato et al., 2012; Rowland \& Jovanoski, 2004; Thompson, 1994). For example, let's consider $f(t)=V$ is the volume of water (in milliliters) in a bottle filled with a constant flow rate as a function of time (in seconds). In this context, for the question asking about the meaning of the symbolic expression $\frac{d}{d t} f(3)=f^{\prime}(3)=0,2$ in the given context, the way of thinking like "the volume of water increased by 0,2 milliliters at the $3^{\text {rd }}$ second" is an example of considering derivative as an amount of change. This is a typical answer provided by students about the contextual meaning of the derivative at a point (Bingolbali, 2008; Kertil, 2014; Thompson, 1994). 
Students also have difficulties in conceiving speed as a rate of change in motion context, they consider it as an amount of distance covered in 1 hour (Kertil, 2014; Thompson, 1994). Similarly, Mkhatshwa (2018) reported that calculus students studying at the business major department regarded marginal cost (or marginal revenue) interpretations of the derivative as an amount of change in the dependent variable. According to Cooney and others (2010), this is the result of a commonly used practice in curricular documents that focus on the changes in the dependent variable for a fixed (1 unit) amount of change in the independent variable. As an example, although considering the speed concept as "distance covered in 1 hour" or marginal cost concept as "change in total cost for producing 1 additional product" is not wrong, this way of thinking may prevent students from conceptualizing the derivative as a rate of change. Besides, because this way of thinking is discrete and chunky (how much change occurs in the dependent variable for a fixed (1 unit) amount of change in the independent variable), it does not support the idea of rate (Thompson, 1994). In other words, for a quotient $\frac{\Delta y}{\Delta x}$, if we keep the changes in $\mathrm{x}$ constant with 1 unit $(\Delta x=1)$, then we will get the same numerical value for the quotient $\frac{\Delta y}{\Delta x}$ and for the amount of change in y ( ${ }^{\Delta y}$ ) even if their units are not the same. To overcome this situation, Cooney and others (2010) offer instead of keeping the changes in the independent variable constant with 1 unit, using unequal amounts of changes to force students for proportional reasoning.

Another difficulty with the understanding of "rate of change" may be lexical which is related to the language used for it (e.g., Bezuidenhout, 1998; de Beer et al., 2015; White \& Mitchelmore, 1996). Many research studies have reported that students did some irrelevant operations like taking the average of a function in an interval when they were asked to find the average rate of change of the function. This result has also been reported for Turkish students (Bingolbali, 2008; Kertil, 2014; Kertil et al., 2017). According to White and Mitchelmore (1996), student difficulties in explaining for which quantities the symbols in the $\frac{d y}{d x}$ expression stand for may be one of the reasons for the language difficulties with the rate of change. Difficulty in giving meaning to the "rate of change" term in different languages may indicate a lexical difficulty as well as it may also be related to the lack of emphasis on this concept in curricular materials like textbooks (Bingolbali, 2008).

On the other side, insufficient emphasis on the rate of change concept in curricular documents generally limited with the motion context has been a commonly reported finding (Berry \& Nyman, 2003; Jones, 2017; Doorman \& Gravemeijer, 2009; Weber \& Dorko, 2014). An overuse of motion context in the teaching of derivative results in student difficulties in giving meaning to this concept in different real-life contexts (Bektaşlı \& Çakmaklı, 2011; Berry \& Nyman, 2003; Jones, 2017; Mkhatshwa, 2016, 2018; Mkhatshwa \& Doerr, 2018; Wilhelm \& Confrey, 2003; Zandieh \& Knapp, 2006). Besides, 
because students become familiar with the speed concept from many earlier grades, they do not need in-depth thinking on it and so they miss the idea of the rate of change (Bezuidenhout, 1998; Thompson, 1994). Research studies also report some other student difficulties such as interpreting the rate of change in the real-life contexts involving decreasing functions with negative rates (Ärlebäck et al., 2013; Ärlebäck \& Doerr, 2018) and interpreting the rate of change in exponential situations (Confrey \& Smith, 1994; Ellis et al., 2015; Stroup, 2002).

\section{METHODOLOGY}

In the current study, while analyzing the mathematics textbooks, we used document analysis which is one of the qualitative research methods. The document analysis method involves analyzing the content of the documents involving information about the topic of interest (Yıldırım \& Şimşek, 2011). Textbooks, as being an important guide for teachers, always are important curricular documents worth investigating.

\section{Selection of the mathematics textbooks as data sources}

Derivative topic is a $12^{\text {th }}$ class-level learning sub-domain of algebra involved in the 9-12 Mathematics Curriculum in Turkey. As we focused on the rate of change interpretation of the derivative, $12^{\text {th }}$-grade mathematics textbooks were selected for analysis. We found three mathematics textbooks in total have been approved by the Board of Education (TTKB) and still are being thought in high schools following the Ministry of Education (MEB) curricula. So, we analyzed the following three textbooks.

- Textkook-1 (Kemancı, Büyükokutan, Çelik ve Kemancı, 2020),

- Textbook-2 (Emin, Gerboğa, Güneş ve Kayacıer, 2020),

- Textbook-3 (Altun, 2018).

According to the MEB (2018) 9-12 mathematics curricula, the derivative learning domain consist of (i) limits and continuity, (ii) rate of change and derivative, and (iii) applications of derivative sub-topics. As the rate of change interpretation of the derivative was focused in this study, the "limits and continuity" sub-topic was not considered for analysis.

\section{Data analysis}

From the quantitative reasoning perspective, for the coverage of derivative as a rate of change in the mathematics textbooks, (i) diversity of real-life contexts (ii) the usage of the quantities with their units and making interpretations (iii) the idea of covariation and (iv) the idea of relative-size have been determined as the themes of analysis.

(i) Context diversity: Under this theme, the variety of the real-life contexts (e.g., kinematics, economics, area-volume, etc.) used in the textbooks have been analyzed. 
(ii) Using and interpreting units: Under this theme, we analyzed if the textbooks provided explanations for the "average" or "instantaneous" rate of change or not, and if they provided explanations, how they interpreted them with the units of quantities.

(iii) The idea of covariation: Under this theme, it was analyzed that if the simultaneous change in two quantities was emphasized or not in the examples or interpretations on the rate of change. For leading students into the simultaneous changes in two quantities, the usage of situations involving dynamically changing quantities other than "time" that can be directly observable has been suggested. For example, the idea of covariation is not obvious in "distance as a function of time" since "time" is an abstract quantity. Volume as a function of height in a filling water context, on the other hand, the idea of covariation is more apparent as both quantities are directly and dynamically observable, so it has a higher potential to lead students into covariational reasoning. In the current study, the examples, questions, activities, and assessment questions used in the textbooks have been analyzed in terms of emphasizing the idea of covariation directly or their potentials to direct students to covariational reasoning. We also analyzed, to what extent the idea of covariation was emphasized in the contexts involving time as an independent variable.

(iv) The idea of relative-size: Under this theme, we analyzed if the derivative as a rate of change was emphasized or interpreted as a relative-size (for any sized change in the independent variable will result in a change in the dependent variable as how many times as much) with the idea of linear approximation or not.

\section{FINDINGS}

The findings obtained from the analysis of three textbooks are reported under the subtitles of (i) context diversity, (ii) Usage of units and interpreting with them, and (iii) covariation and relative size ideas.

\section{Context diversity}

For the context diversity, the exercises, tasks and activities, projects, and end-of-unit assessment items including the lecturing parts covered in each of the textbooks were analyzed in terms of the contexts presented. The frequency of context-free contents, totally presented in symbolic (algebraic) forms, have also been included in the table. 
Table 1

Analysis of the textbooks in terms of the context diversity used for derivative topic

\begin{tabular}{lccc}
\hline & $\begin{array}{c}\text { Textbook-1 } \\
\mathrm{f}(\%)\end{array}$ & $\begin{array}{c}\text { Textbook-2 } \\
\mathrm{f}(\%)\end{array}$ & $\begin{array}{c}\text { Textbook-3 } \\
\mathrm{f}(\%)\end{array}$ \\
\hline Motion context (Kinematics) & $12(7,5 \%)$ & $12(6 \%)$ & $9(5 \%)$ \\
Slope of tangent line & $10(6 \%)$ & $13(6 \%)$ & $8(4,5 \%)$ \\
Economics (profit-loss, cost) & $3(2 \%)$ & $5(2,5 \%)$ & $1(0,6 \%)$ \\
Population & $1(0,6 \%)$ & - & - \\
Length-area-volume & $10(6 \%)$ & $15(7,3 \%)$ & $17(9,4 \%)$ \\
Context-free & $125(78 \%)$ & $160(78 \%)$ & $146(81 \%)$ \\
\hline Total & $161(100 \%)$ & $205(100 \%)$ & $181(100 \%)$
\end{tabular}

Note: All the content including end-of-unit assessment questions was considered for analysis.

In three of the textbooks, for the content of the derivative topic, an overuse of contextfree elements and materials (purely algebraic exercises or activities without a real-life context) is observable. The rate of change interpretation of the derivative is generally introduced in motion context using the speed or acceleration concepts. The slope of tangent line supported with algebraic and graphical representation is the other frequently emphasized interpretation. Non-motion real-life contexts are seldomly used for exemplifying and interpreting the derivative as a rate of change. Economy and length-area-volume contexts are commonly used under the "application of derivative" sub-topic in the form of optimization problems. However, in the optimization problems, rather than interpreting the meaning of what the derivative is, the focus is more on procedural applications such as finding the critical points, max-min points, inflection point, and determining the intervals in which the function increases or decreases. 


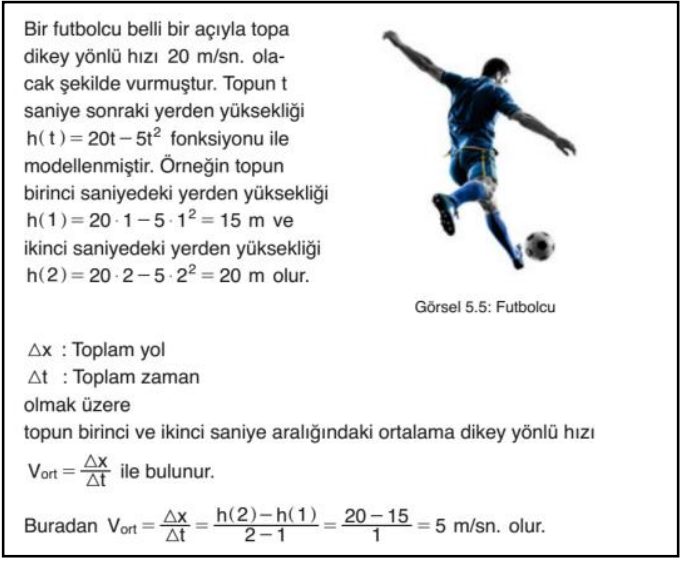

Figure 3. An introduction to the rate of change interpretation of derivative in Textbook-1 (p. 266)

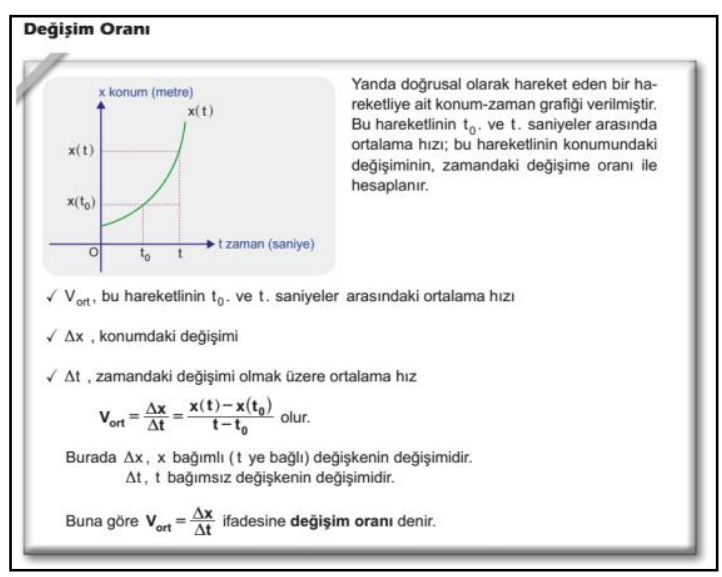

Figure 4. An introduction to the rate of change interpretation of derivative in Textbook-2 (p. 213)

As seen in Figure 3 and Figure 4, the rate of change interpretation of derivative is started with the "average speed" concept. In both textbooks. In Textbook-1, the kinematic context is frequently used in most of the exercises. Looking at the end of unit assessment questions, we observed that three items from the economy context (marginal cost, marginal revenue, and marginal profit) were used for the rate of change interpretation of derivative. However, in the lecturing part of the textbook content, we could not see any task, activity, or exercise provided as an example for interpreting the rate of change in a context from the economy. In Textbook-2, on the other hand, we could not observe the usage of any other real-life context other than motion as an example for the rate of change.
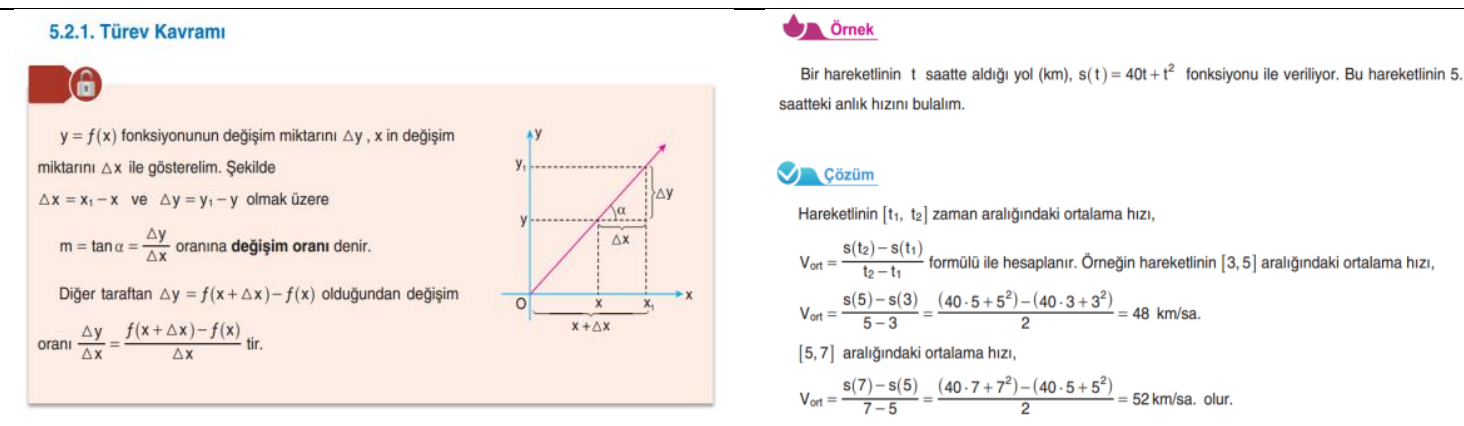

Figure 5. An introduction to the rate of change in Textbook-3 (p. 179-180)

In Textbook-3, the rate of change interpretation of the derivative is first introduced by slope and difference quotient supported with a graphical representation without using any real-life context. Right after, an exercise from kinematic context is provided. In the following exercises, a context from the economy was used only once in an example 
asking about the fuel consumption as a function of distance covered. All in all, for three of the textbooks, it is difficult to say that the context diversity concerning the derivative as a rate of change is good enough.

\section{Usage of the units and interpreting with them}

As we checked out the explanations in lecturing parts or the solutions of the exercises, we focused on all of the content excluding end-of-unit questions.

Table 2

Usage of units and interpreting with them across the textbooks

\begin{tabular}{lccc}
\hline & $\begin{array}{c}\text { Textbook-1 } \\
(\mathrm{n}=6) \mathrm{f}(\%)\end{array}$ & $\begin{array}{c}\text { Textbook-2 } \\
(\mathrm{n}=14) \mathrm{f}(\%)\end{array}$ & $\begin{array}{c}\text { Textbook-3 } \\
(\mathrm{n}=11) \mathrm{f}(\%)\end{array}$ \\
\hline $\begin{array}{l}\text { Complete and proper } \\
\text { use of the units }\end{array}$ & $6(100 \%)$ & $12(86 \%)$ & $8(73 \%)$ \\
$\begin{array}{l}\text { In-depth interpretations } \\
\text { by using the units }\end{array}$ & $1(17 \%)$ & $2(14 \%)$ & $2(18 \%)$ \\
$\begin{array}{l}\text { Improper use or non- } \\
\text { use of the units }\end{array}$ & - & $2(14 \%)$ & $11(100 \%)$ \\
\hline \begin{tabular}{l} 
Total \\
\hline
\end{tabular}
\end{tabular}

Note: For this part, end-of-unit assessment questions are excluded.

In three of the textbooks, usually, the units of quantities are properly used in the contextual tasks and materials, but a lack of in-depth interpretations is observable. In all of the textbooks, the units are properly and completely used in the contextual tasks or exercises involving speed or acceleration concepts. However, improper or incomplete usage of the units is observed in some of the optimization problems. In-depth verbal interpretations on the meaning of rate of change are seldomly observed in all of the textbooks, generally limited with the kinematic context in the parts where the rate of change concept was first introduced. In three of the textbooks, for a vehicle with a speed of $40 \mathrm{~km} / \mathrm{h}$, for instance, in-depth interpretation on the meaning of this numerical value as a verbal expression of rate of change with the quantities involved and their units is not emphasized enough. There is no detailed explanation on the meaning of $40 \mathrm{~km} / \mathrm{h}$ speed for a moving vehicle, for example, provided with the examples of guessing the approximate distance covered by it, for example, in 1 second or in 5 seconds. 


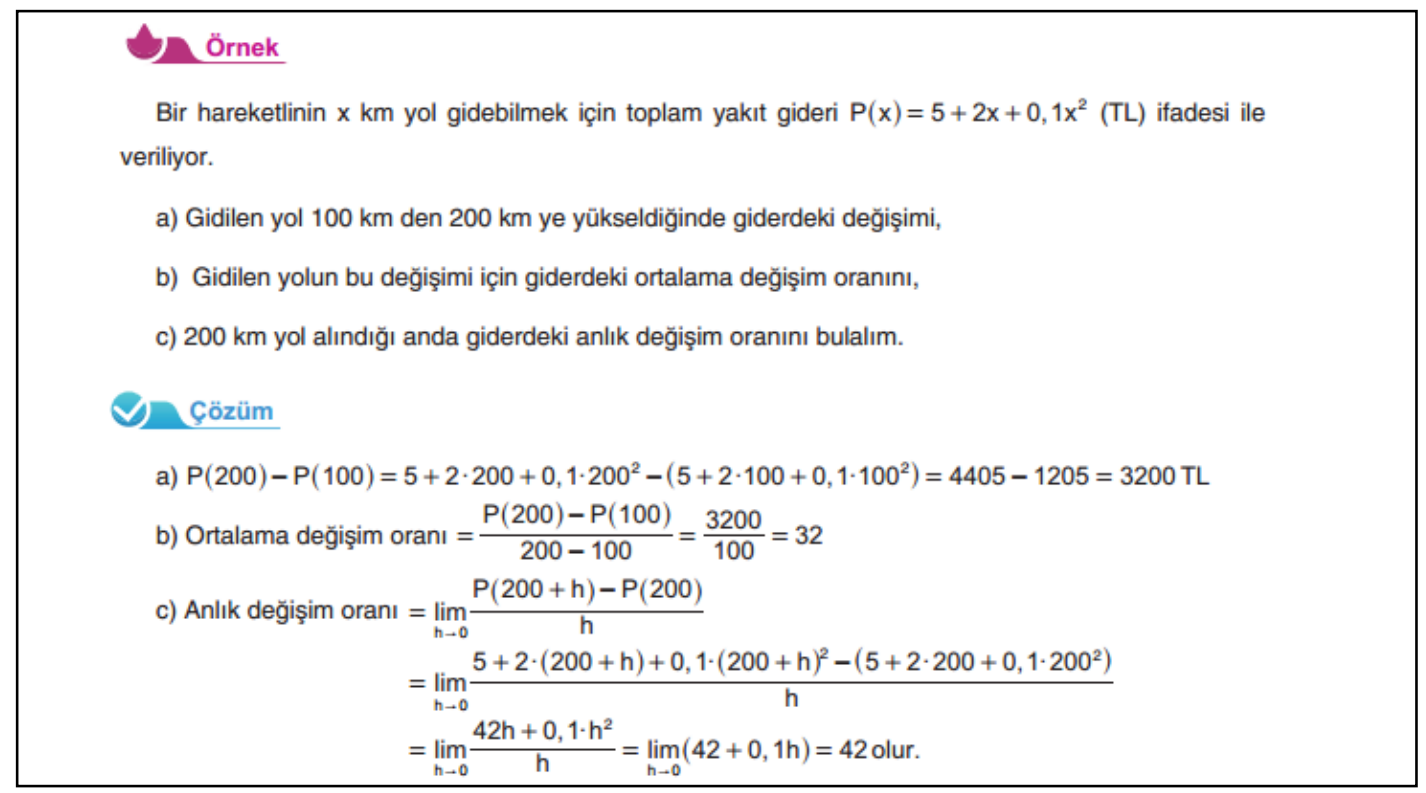

Figure 6. A sample exercise with its solution used in Textbook-3

In the exercise from Textbook-3 in Figure 6, it was asked to find the average and instantaneous rate of change in the cost of fuel conception of moving vehicle as a function of distance covered. As seen in Figure 6, the numerical values are computed for average and instantaneous rate of change, for $b$ and c parts of the exercise respectively, but the units are not emphasized. Although the above exercise has the potential to be a good example of non-kinematic context for the rate of change, the absence of units $(\mathrm{TL} / \mathrm{km})$ and lack of in-depth interpretation of their meaning is the critical matter. In part-c, for example, the numerical value $(42 \mathrm{TL} / \mathrm{km})$ of the instantaneous rate of change in the cost of fuel consumption is computed. But there are no interpretations like "at the instant of 200th kilometer, as the vehicle goes 1 more kilometer, an extra cost of fuel consumption will be about $42 \mathrm{TL}$ ". This situation, as relative size, can be expressed as "beginning from the 200th kilometer, the cost of the fuel consumption will be 42 times as much of the distance covered". An extra 42 TL increase in the cost of fuel consumption per kilometer of distance covered can not be possible in reality. In-depth interpretations of the rate of change in the given contexts will also help students to understand the authenticity of the given set-up context as observed in the exercise provided in Figure 6. 


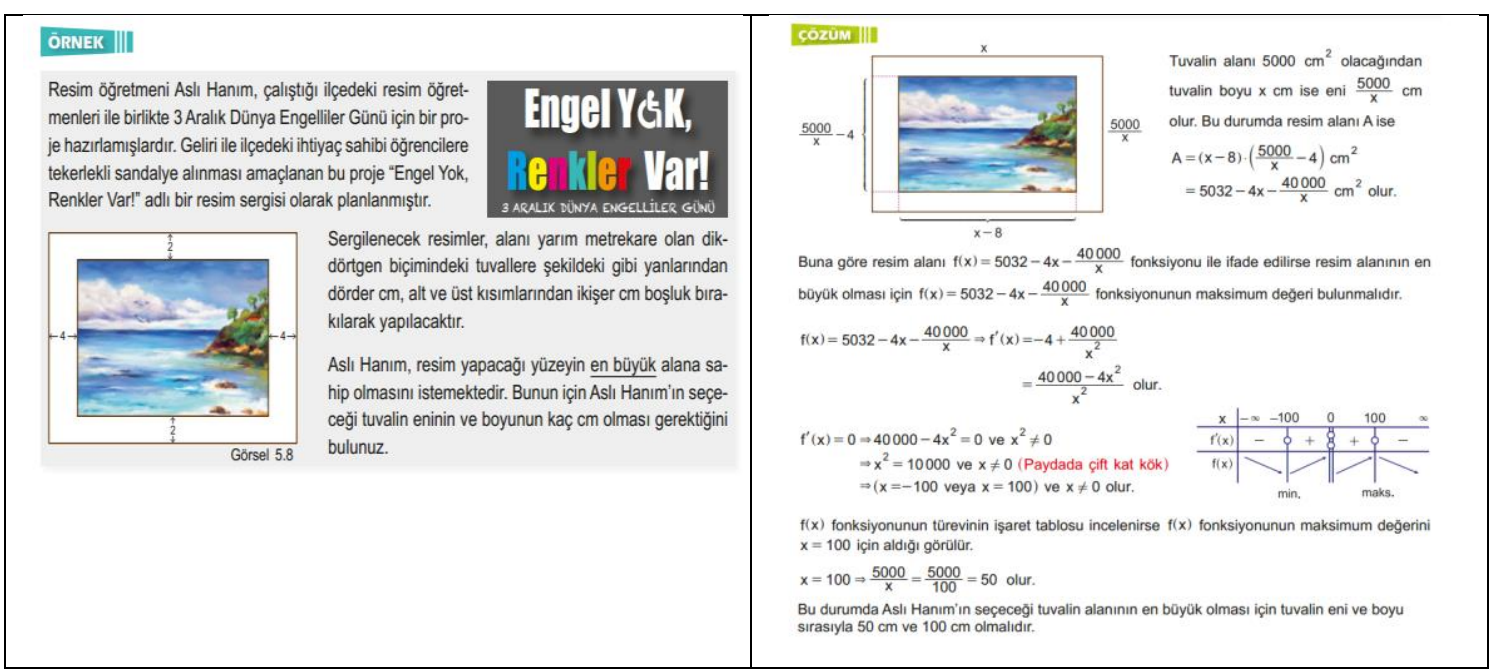

Figure 7. An exercise with its solution used in Textbook-2 (p. 280).

Especially, in the optimization problems frequently used in the applications of derivative sub-domain, the usage of units for derivative functions barely appear in any of the exercises or tasks. In Figure 7, an optimization problem on finding the dimensions of a canvas to maximize its area. In the example above, although the area of canvas is provided as a function of its outer length, the units of the derivative function are not written and there is no interpretation of its meaning. This is a common situation in three of the textbooks. Even though in-depth interpretations on the meaning of derivative are not a requirement in optimization problems, the contexts in these problems can be seen as an opportunity for emphasizing the meaning of the derivative in different contexts. In the optimization problems, procedures like taking the first derivative for finding the critical points are the primary focus. There are no interpretations about the meaning of derivative in general or what the zero as the value of derivative means in the given context.

\section{Covariation and relative size ideas}

The descriptive frequencies of covariation and relative size ideas that appeared in the exercises, activities, and end-of-unit assessment questions used in the textbooks are presented in Table 3. 
Table 3.

Covariation and relative size ideas related to derivative in three of the textbooks

\begin{tabular}{|c|c|c|c|c|}
\hline & & $\begin{array}{c}\text { Textbook-1 } \\
(n=26)\end{array}$ & $\begin{array}{c}\text { Textbook-2 } \\
(n=32)\end{array}$ & $\begin{array}{c}\text { Textbook-3 } \\
(n=27)\end{array}$ \\
\hline The idea of & $\begin{array}{l}\text { Potential } \\
\text { content }\end{array}$ & $9(35 \%)$ & $12(38 \%)$ & $13(48 \%)$ \\
\hline covariation & Interpretation & 0 & 0 & $1(4 \%)$ \\
\hline $\begin{array}{l}\text { The idea of relative- } \\
\text { size }\end{array}$ & & 0 & 0 & 0 \\
\hline Total & & $26(100 \%)$ & $32(100 \%)$ & $27(100 \%)$ \\
\hline
\end{tabular}

Note: Content involving a real-life context including end of the unit questions was considered

As seen in Table 3, the contents of the three textbooks are weak in terms of emphasizing and interpreting the ideas of covariation and relative size. In Textbook-3, the idea of covariation is emphasized in only one exercise from motion context in which the values of distance and time quantities are given as tabular data, and the idea of instantaneous rate of change is related to radar. Again in Textbook-3, in an example using the context of the cost of fuel consumption as a function distance (see Figure 6), the covariation and relative size ideas were not emphasized or elaborated even though the given nonkinematic context was more appropriate to do it.

In three of the textbooks, some contents have the potential to support the idea of covariation. However, it is observable that most of these contents appear in the applications of the derivative part (optimization and max-min problems). As indicated previously, in optimization problems, derivative is generally used procedurally (equating the derivative function to zero for finding the critical points, analyzing the sign of the second derivative, etc.), without any interpretations on its meaning in the given context. Therefore, the opportunity of fostering covariation and relative size ideas are missed in the contexts used in the optimization problems, without a time variable, such as area as a function of length, volume as a function of height, and total profit as a function of ticket sold. Indeed, the dynamic animations of the contexts like area or volume of a geometric figure or solid as function of its length of a dimension can easily be constructed in dynamic geometry programs such as Geogebra, Geometry Sketchpad, Cabri, or Desmos. These animations may foster the idea of covariation (showing the dynamic nature of simultaneous changes in two quantities) as well as they can contribute to the idea of function as a dynamic change and the idea of the rate of change 
as relative size. One of the exercises carrying out a dynamic animation potential is presented in Figure 8 below.

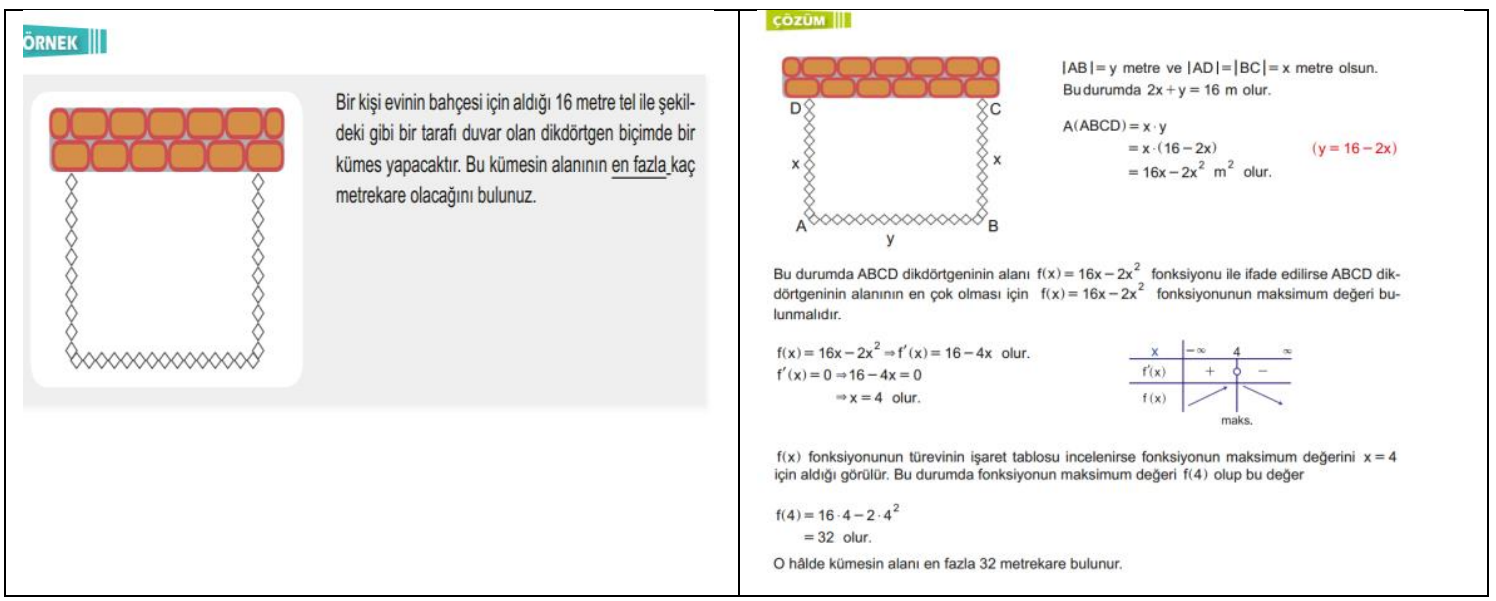

Figure 8. An exercise from area-length context used in Textbook-2 (p. 276)

In the exercise provided in Figure 8, in addition to the algebraic equation for $A(x)$, the dynamic and simultaneous changes in length $(\mathrm{x})$ and area $(\mathrm{A}(\mathrm{x}))$ quantities with tabular data can be observed within a dynamic geometry environment. Further to that, here an emphasis on the verbal interpretation that "for any sized change in the length of its short side, the area of the rectangle will change how many times as much" may contribute to students' understanding of the derivative as relative size (and smooth covariation). Similarly, the interpretations like "change in area per unit change in the length" may also contribute to students giving meaning to the derivative even though it involves a chunky way of covariational reasoning.

\section{DISCUSSION AND CONCLUSION}

As pointed out in the literature review part, derivative and its rate of change interpretation form a basis for further calculus concepts. Because of its extensive usage area, a robust understanding of the derivative is not only important for the understanding of further calculus concepts but also critical for students' mathematical literacy. However, from past to present, some common student and teacher difficulties related to the understanding of the derivative have been reported (e.g., Berry \& Nyman, 2003; Bezuidenhout, 1998; Byerley \& Thompson, 2017; Gökçek \& Açıkyıldız, 2016; Herbert \& Pierce, 2011; Mkhatshwa \& Doerr, 2018). The concept of derivative, from the quantitative reasoning perspective, has been defined as "a new quantity obtained as a result of multiplicative comparison of the changes in two quantities", and this perspective indicates the importance of giving meaning to derivative in different real-life contexts as a quantity (Thompson, 1994; 2011). In this study, initially, the meaning of derivative has been analyzed from the quantitative reasoning perspective. Later on, we analyzed the 
mathematics textbooks still being thought in Turkey, by using the principles derived from quantiative reasoning theory which are; (i) context diversity, (ii) usage of units and interpreting with them, (iii) covariation, and (iv) relative size.

In all of the textbooks, it was observed that kinematic contexts were frequently used in the content involving exercises, activities, and assessment questions, but economy or non-temporal contexts in which "time" does not appear as a variable were scarcely used (see Table 1). Even, content without a real-life context (context-free) requiring only procedural and algebraic operations was predominantly used in three of the textbooks. Contexts like length-area-volume are frequently used in optimization problems (in applications of the derivative part) but without in-depth interpretations of the meaning of derivative. Therefore, we can conclude that the derivative concept was introduced limited with the kinematic context. This finding is not only special to Turkey, but also the overuse of kinematic context in the curricular materials related to the derivative topic has also been reported in many international studies (e.g., Byerley \& Thompson, 2017; Jones, 2017; Mkhatshwa \& Doerr, 2018; Weber \& Dorko, 2014). This study confirms the same problem with the Turkish mathematics textbooks.

Looking at the usage of the units, in three of the textbooks, units are properly used but there is not enough emphasis on in-depth interpretations on the rate of change by using the units of quantities. The review of literature also points out that an insufficient emphasis on the idea of covariation in curricular materials is one of the reasons for student and teacher difficulties with the concept of derivative (e.g., Carlson et al., 2002; Thompson \& Carlson, 2017; Cooney et al., 2010; Castillo-Garsow, 2012; Byerley \& Thompson, 2017; Thompson, 1994). In the current study, there is no emphasis on covariation and relative-size ideas too in the textbooks analyzed. Although there are some exercises from different non-temporal real-life contexts in which dynamic changes can be directly observable and so having a great potential to foster the idea of covariation, these contexts generally appear in optimization problems. However, there is no interpretation about the meaning of the derivative in the optimization problems, only the procedures such as equating the derivative function to zero to find the critical and max-min points are observable. As indicated previously, not focusing on the meaning of the derivative in different contexts used in the optimization problems can be seen as a missed opportunity. Yet, derivative and rate of change will gain a different meaning and identity for students in every distinct real-life context. For example, the derivative will be called as flow rate for the amount of water in a draining dam as a function of time context; it will be acceleration for a speed as a function of time context; it will be called as marginal cost in total cost as a function of product context; it will be a cross-sectional area for a volume of water as a function of height in a filling-tank context. Indeed, the concept of rate of change gains different meanings in each context even though all they involve the rate of change interpretation of derivative. Therefore, it is critical to provide students with exeriences in interpreting the derivative as a rate of change in different 
contexts to increase their awareness about diverse meanings which is emphasized by the theory of quantitative reasoning.

Any interpretations emphasizing the relative size idea of the rate of change is another lacking point in three of the textbooks. The rate of change interpretation of derivative as relative size is important in terms of conceiving derivative as a rate in different real-life contexts (Byerley \& Thompson, 2017). This is because, conceiving the derivative as an amount of change in one quantity is a common student misconception reported in many studies (e.g., Byerley \& Thompson, 2017; Mkhatshwa \& Doerr, 2018; Rowland \& Javanoski, 2004; Thompson, 1994). Applications involving linear approximation should be used more frequently for fostering the relative size idea of the derivative. Besides, verbal interpretations like "distance covered per unit time", or "cost for producing one additional product" can be emphasized by associating with the linear approximation method. But, it should not be forgotten here that, thinking by keeping the changes in the independent variable by 1 unit may result in conceiving the derivative as an amount of change in the dependent variable (because $\frac{\Delta y}{\Delta x}$ and $\Delta y$ will take the same numerical value when $\Delta x=1$ ) (Cooney et al., 2010; Mkhatshwa, 2018). So, applications and practices on, for example, interpreting the meaning of derivative at a point in terms of the quantities involved and guessing the approximate value of the function around that point by using the derivative value (i.e., what would happen to the value of function if the independent variable changes with 0,0002 units) may contribute to the idea of relative-size. Moreover, discussing the meaning of marginal cost, for example, in terms of the infinitesimal change in the independent variable may increase students' awareness about some problematic aspects of the interpretations of the derivative in different fields (Mkhatshwa, 2018; Mkhatshwa \& Doerr, 2018).

Consequently, although the rate of change meaning of derivative was covered in the textbooks, it is generally limited with the kinematic context and there are no in-depth interpretations. More frequent usage of contextual content is an obvious necessity in which "time" is not used as an independent variable and has the potential to reveal dynamic and simultaneous changes in two quantities to foster the idea of covariation. Showing the dynamic animations of simultaneous change in two quantities may help students to focus on covariational reasoning (Kertil, 2020). The learning activities prepared by using the dynamic geometry software can be used as an opportunity for this. Besides, the idea of relative size should be supported with the covariation and linear approximation practices within different contexts. 


\section{References}

Altun, M. H. (2018). Matematik 12. sinif ders kitabı [Mathematics grade 12 textbook]. Ankara: Tutku Yayıncılık.

Ärlebäck, J. B., Doerr, H. M., \& O'Neil, A. M. (2013). A modeling perspective on interpreting rates of change in context. Mathematical Thinking and Learning, 15(4), 314-336.

Ärlebäck, J. B., \& Doerr, H. M. (2018). Students' interpretations and reasoning about phenomena with negative rates of change throughout a model development sequence. ZDM-Mathematics Education, 50, 187-200.

Bektaşlı, B., \& Çakmakçı, G. (2011). Consistency of students' ideas about the concept of rate across different contexts. Education and Science, 36 (162), 273-287.

Berry, J. S., \& Nyman, M. A. (2003). Promoting students' graphical understanding of the calculus. The Journal of Mathematical Behavior, 22, 481-497.

Bezuidenhout, J. (1998). First year university students' understanding of rate of change. International Journal of Mathematical Education in Science and Technology, 29(3), 389-399.

Byerley, C., \& Thompson, P. (2017). Secondary mathematics teachers' meanings for measure, slope, and rate of change. The Journal of Mathematical Behavior, 48, 168193.

Byerley, C. (2019). Calculus students' fraction and measure schemes and implications for teaching rate of change functions conceptually. The Journal of Mathematical Behavior, $55,100694$.

Bingolbali, E. (2008). Türev kavramına ilişkin öğrenme zorlukları ve kavramsal anlama için öneriler [Learning difficulties related to the concept of derivative and suggestions for conceptual understanding]. M. F. Özmantar, E. Bingolbali, \& H. Akkoç (Eds.), Matematiksel kavram yanılgıları ve çözüm önerileri (pp. 223-255). Ankara: Pegem A.

Bingolbali, E. \& Bingolbali, F. (2020). An examination of tasks in elementary school mathematics textbooks in terms of multiple outcomes and multiple solution methods. International Journal of Educational Studies in Mathematics, 7(4), 214-235.

Carlson, M., Jacobs, S., Coe, E., Larsen, S., \& Hsu, E. (2002). Applying covariational reasoning while modeling dynamic events. Journal for Research in Mathematics Education, 33(5), 352-378.

Castillo-Garsow, C. (2012). Continuous quantitative reasoning. In R. L. Mayes, \& L. Hatfield (Eds.), Quantitative reasoning and mathematical modeling: A driver for STEM integrated education and teaching in context (pp. 55-73). Laramie: University of Wyoming Press.

Confrey, J. \& Smith, E. (1994). Exponential functions, rates of change, and the multiplicative unit. Educational Studies in Mathematics, 26(2/3), 134-165. 
Cooney, T. J., Beckman, S., \& Lloyd, G. M. (2010). Developing essential understanding of functions for teaching mathematics in grades 9-12. Reston, VA: National Council of Teachers of Mathematics.

de Almeida, L.M.W. \& da Silva, K.A.P. (2018). A semiotic interpretation of the derivative concept in a textbook. ZDM Mathematics Education 50, 881-892. https://doi.org/10.1007/s11858-018-0975-8

Doorman, L. M., \& Gravemeijer, K. P. E. (2009). Emergent modeling: discrete graphs to support the understanding of change and velocity. ZDM Mathematics Education 41(12), 199-211. https://doi.org/10.1007/s11858-008-0130-z

Ellis, A. B., Ozgur, Z., Kulow, T., Williams, C. C., \& Amidon, J. (2015). Quantifying exponential growth: Three conceptual shifts in coordinating multiplicative and additive growth. The Journal of Mathematical Behavior, 39, 135-155. doi:10.1016/j.jmathb.2015.06.004

Emin, A., Gerboğa, A., Güneş, G. \& Kayacıer, M. (2020). Matematik 12. sınıf ders kitabı [Mathematics grade 12 textbook]. Ankara: MEB yayınları.

Gökçek, T., \& Açıkyıldız, G. (2016). Matematik öğretmeni adaylarının türev kavramıyla ilgili yaptıkları hatalar [Preservice mathematics teachers' errors related to derivative]. Turkish Journal of Computer and Mathematics Education, 7(1), 112-141.

Hawson, G. (2013). The development of mathematics textbooks: historical reflections from a personal perspective. ZDM Mathematics Education, 45, 647-658.

Herbert, S., \& Pierce, R. (2011). What is rate? Does context or representation matter? Mathematics Education Research Journal, 23(4), 455-477.

Herbert, S., \& Pierce, R. (2012). Revealing educationally critical aspects of rate. Educational Studies in Mathematics, 81(1), 85-101.

İncikabı, L. \& Tjoe, H. (2013). A comparative analysis of ratio and proportion problems in Turkish and the U.S. middle school mathematics textbooks. Ahi Evran Üniversitesi Kırşehir Eğitim Fakültesi Dergisi (KEFAD), 14(1), 1-15.

Jones, S. R. (2017). An exploratory study on student understandings of derivatives in real-world, non-kinematics contexts. The Journal of Mathematical Behavior, 45, 95110.

Kemancı, B., Büyükokutan, A., Çelik, S. \& Kemancı, Z. (2020). Fen lisesi 12. sinıf matematik ders kitabı [Science high school 12th grade math textbook]. Ankara: MEB yayınları.

Kertil, M. (2014). Pre-service elementary mathematics teachers' understanding of derivative through a model development unit (Unpublished doctoral dissertation). Middle East Technical University, Graduate School of Natural and Applied Sciences, Ankara.

Kertil, M. (2020). Covariational reasoning of prospective mathematics teachers: How do dynamic animations affect? Turkish Journal of Computer and Mathematics Education, 11(2), 312-342. doi:10.16949/turkbilmat.652481. 
Kertil, M., Erbaş, A. K., \& ve Çetinkaya, B. (2017). İlköğretim matematik öğretmen adaylarının değişim oranı ile ilgili düşünme biçimlerinin bir modelleme etkinliği bağlamında incelenmesi [Examination of primary school mathematics teacher candidates' thinking about rate of change in the context of a modeling activity.]. Turkish Journal of Computer and Mathematics Education, 8(1), 188-217.

Kertil, M., Erbaş, A. K., \& Çetinkaya, B. (2019). Developing prospective teachers' covariational reasoning through a model development sequence. Mathematical Thinking and Learning, 21, 207-233.

Lobato, J., Hohensee, C., Rhodehamel, B., \& Diamond, J. (2012). Using student reasoning to inform the development of conceptual learning goals: The case of quadratic functions. Mathematical Thinking and Learning, 14(2), 85-119.

MEB (2018). Ortaöğretim Matematik Dersi (9-12. Sınıflar) Öğretim Programı [Secondary Education Mathematics (Grades 9-12) Curriculum]. Ankara: Milli Eğitim Bakanlığı Yayınları.

Mkhatshwa, T. P. (2016). Business calculus students' reasoning about optimization problems: A study of quantitative reasoning in an economic context (Doctoral dissertation). New York, NY: Syracuse University.

Mkhatshwa, T. P. (2018). Business calculus students' interpretations of marginal change in economic contexts. In Hodges, T.E., Roy, G. J., \& Tyminski, A. M. (Eds.), Proceedings of the 40th Annual Meeting of the North American Chapter of the International Group for the Psychology of Mathematics Education (pp. 564-571). Greenville, SC: University of South Carolina \& Clemson University.

Mkhatshwa, T., \& Doerr, H. (2018). Undergraduate students' quantitative reasoning in economic contexts. Mathematical Thinking and Learning, 20(2), 142-161. https://doi.org/10.1080/10986065.2018.1442642

Park, J. (2016). Communicational approach to study textbook discourse on the derivative. Educational Studies in Mathematics, 91, 395-421. https://doi.org/10.1007/s10649-015-9655-6

Randahl, M., \& Grevholm, B. (2010). Learning opportunities in a classical calculus book. Nordic Studies in Mathematics Education, 15(2), 5-27.

Rowland, D. R., \& Jovanoski, Z. (2004). Student interpretation of the terms in first-order ordinary differential equations in modeling contexts. International Journal of Mathematical Education in Science and Technology, 35(4), 505-516.

Schmidt, W. H. (2012). Measuring content through textbooks: The cumulative effect of middle-school tracking. In G. Gueudet, B. Pepin, \& L. Trouche (Eds.), From text to 'Iived' resources: Mathematics curriculum materials and teacher development (pp. 143-160). Dordrecht: Springer. 
Schwartz, J. (1988). Intensive quantity and referent transforming arithmetic operations. In J. Hiebert \& M. Behr (Eds.), Number concepts and operations in the middle grades (pp. 41-52). Reston, VA: NCTM.

Stroup, W. (2002). Understanding qualitative calculus: A structural synthesis of learning research. International Journal of Computers for Mathematical Learning, 7(2), 167215.

Teuscher, D. \& Reys, R. E. (2012). Rate of change: AP calculus students' understandings and misconceptions after completing different curricular paths. School Science and Mathematics, 112(6), 359-376. https://doi.org/10.1111/j.1949-8594.2012.00150.x

Thompson, P. W. (1994). Images of rate and operational understanding of the fundamental theorem of calculus. Educational Studies in Mathematics, 26, 229-274.

Thompson, P. W. (2011). Quantitative reasoning and mathematical modeling. In L. L. Hatfield, S. Chamberlain, \& S. Belbase (Eds.), New perspectives and directions for collaborative research in mathematics education (Vol. 1, pp. 33-57). Laramie, WY: University of Wyoming.

Thompson, P. W., \& Carlson, M. P. (2017). Variation, covariation, and functions: Foundational ways of thinking mathematically. In J. Cai (Ed.), Compendium for research in mathematics education (pp. 421-456). Reston, VA: National Council of Teachers of Mathematics.

Thompson, P. W., Hatfield, N. J., Yoon, H., Joshua, S., \& Byerley, C. (2017). Covariational reasoning among U.S. and South Korean secondary mathematics teachers. The Journal of Mathematical Behavior, 48, 95-111.

Weber, E. \& Dorko, A. (2014). Students' and experts' schemes for rate of change and its representations. The Journal of Mathematical Behavior, 34, 14-32.

Wilhelm, J. A. \& Confrey, J. (2003). Projecting rate of change in the context of motion onto the context of money. International Journal of Mathematical Education in Science and Technology, 34(6), 887-904. https://doi.org/10.1080/00207390310001606660

Yavuz, İ. \& Baştürk, S. (2011). Ders kitaplarında fonksiyon kavramı: Türkiye ve Fransa örneği. Kastamonu Eğitim Dergisi, 19(1), 199-220.

Yıldırım, A. \& Şimşek, H. (2011). Sosyal bilimlerde nitel araştırma yöntemleri [Qualitative research methods in the social sciences]. Ankara: Seçkin Yayıncılık.

Zandieh, M. (2000). A theoretical framework for analyzing students' understanding of the concept of derivative. In E. Dubinsky, A. H. Schoenfeld, \& J. Kaput (Eds.), Research in collegiate mathematics education (vol. IV, pp. 103-127). Providence, RI: American Mathematical Society.

Zandieh, M. J., \& Knapp, J. (2006). Exploring the role of metonymy in mathematical understanding and reasoning: The concept of derivative as an example. The Journal of Mathematical Behavior, 25(1), 1-17. https://doi.org/10.1016/j.jmathb.2005.11.002 
In the writing process of the study titled "Conceptual Analysis of Derivative as a Rate of Change and Analysis of the Mathematics Textbooks", the rules of scientific, ethical and citation were followed; it was undertaken by the authors of this study that no falsification was made on the collected data. "Sakarya University Journal of Education Journal and Editor" had no responsibility for all ethical violations to be encountered, and all responsibility belongs to the authors and that the study was not submitted for evaluation to any other academic publishing environment.

\section{Statement of Contribution of Researchers to the Article:}

1st author contribution rate: $100 \%$

Conflict of Interest Statement:

There is no conflict of interest.

Statement of Financial Support or Acknowledgment:

No financial support was received from any institution for this study. 


\section{Türevin Değişim Oranı (Hızı) Yorumunun Kavramsal Analizi ve Matematik Ders Kitaplarının İncelenmesi}

\section{Mahmut KERTIL ${ }^{*}$}

Öz. Bu çalışmada ilk olarak, türevin değişim oranı yorumunun anlamına yönelik kavramsal analizi nicel muhakeme teorik çerçevesinden detaylı olarak açıklanmaktadır. Daha sonra, nicel muhakeme çerçevesinden elde edilen temel prensipler doğrultusunda Türkiye'de okutulan 12. Sınıf matematik ders kitaplarında türev kavramın nasıl ele alındığı nitel araştırma yöntemlerinden doküman inceleme yöntemiyle analiz edilmiştir. Elde edilen bulgular, incelenen ders kitaplarında türev kavramının anlamının tartışıldığı gerçek hayat bağlam çeşitliliğinin yetersiz olduğu ve hatta kinematik bağlamıyla sınırlı olduğunu göstermektedir. Kullanılan farklı gerçek hayat bağlamlarında birimlerin doğru kullanıldığı fakat türevin anlamı üzerine derinlemesine yorumlamaların yeterli olmadığı görülmektedir. İncelenen her üç ders kitabında da türev kavramı ve değişim oranı yorumunun doğru anlaşılması bakımından önemli görülen kovaryasyon ve nispi büyüklük fikirlerinin de yeterince vurgulanmadığı görülmüştür. Ayrıca, türev kavramına yönelik olarak ders kitaplarında güçlendirilmesi gereken yönler vurgulanmıştır. Elde edilen bulgular ışı̆̆ında, türev konusuna ilişkin olarak matematik ders kitaplarında geliştirilmesi gereken yönler, bazı gerçek hayat bağlamlarında türevin değişim oranı ve nispi büyüklük olarak yorumlaması örnekleriyle desteklenerek tartışmalar yapılmıştır.

Anahtar Kelimeler: Değişim oranı (hızı), Kovaryasyon, Matematik ders kitabı, Nicel muhakeme, Türev.

\footnotetext{
* Orcid ID: https://orcid.org/0000-0002-0633-7144, Dr. Marmara Üniversitesi, Türkiye, mkertil@marmara.edu.tr 


\section{GİRIŞ}

Türev kavramı analizin en temel kavramlarından birisi olup ön bilgi olarak oran, eğim ve limit gibi temel birçok matematiksel kavramların iyi anlaşılmasını gerektirmektedir. Değişim oranı (hızı) türevin gerçek hayat bağlamlarındaki en kapsamlı yorumunu teşkil etmekle birlikte, öğrenci ve hatta öğretmenlerin zorlandığı bir kavramdır (Bezuidenhout, 1998; Byerley ve Thompson, 2017; Byerley, 2019; Bingolbali, 2008; Herbert ve Pierce, 2011, 2012). Türev ve değişim oranı yorumuna yönelik öğrenci ve öğretmen zorluklarının en temel sebeplerinden birisi olarak ders kitaplarındaki yetersizlik gösterilmektedir (Bingolbali, 2008; Byerley ve Thompson, 2017; Mkhatshwa, 2016; Mkhatshwa ve Doerr, 2018; Teuscher ve Reys, 2012).

Öğretmen pratiklerini yönlendiren en önemli kaynaklardan biri olan ders kitaplarl, öğretim programının bir yorumlaması olduğundan çeşitli akademik çalışmalara konu olmaktadır (Bingolbali ve Bingolbali, 2020; Howson, 2013; Schmidt, 2012; Yavuz ve Baştürk, 2011). Ders kitaplarını inceleyen çalışmalar genellikle (i) kavramların nasıl ele alındığı, (ii) öğrenci performans beklentilerini karşılama (problem çözme, iletişim vb.), (iii) öğretimsel öğelerin (görsel öğe, tasarım, tablo, grafik kullanımı vb.) değerlendirilmesi ve (iv) ülkeler arası karşılaştırma çalışmaları olarak gruplandırılabilir (Howson, 2013). Farklı gelenek ve bakış açılarının karşılıklı öğreticiliği sebebiyle, ülkeler arası ders kitaplarını kıyaslama çalışmaları da yaygın çalışmalar olarak karşımıza çıkmaktadır (örn. İncikabı ve Tjoe, 2013; Yavuz ve Baştürk, 2011). Belirli bir kavramın ders kitabında nasıl ele alındığı, kullanılan etkinlik ve problemlerin doğası ve çoklu temsillerin kullanımı gibi boyutlarda çok sayıda ders kitabı inceleme çalışması bulunmaktadır (örn., Bingolbali ve Bingolbali, 2020; Yavuz ve Baştürk, 2011). Fakat, literatürde türev kavramına yönelik ders kitabı analizi çalışmaları bulunmakta birlikte (örn., de Almeida ve da Silva, 2018; Park, 2016; Randhal ve Grevholm, 2010) özellikle değişim oranı kavramına odaklanan ders kitabı analizi çalışması bulunmamaktadır. Randahl ve Grandholm (2010) tarafından yapılan çalışmada mühendislik öğrencilerine okutulan kalkülüs kitaplarında türev kavramının daha çok prosedürel bilgi ağırlıklı olarak ele alındığını göstermişlerdir.

Türev kavramının değişim oranı yorumuna yönelik öğrenci ve öğretmen zorluklarının temel sebeplerinden birisi olarak ders kitaplarının görülmesi, ulusal ve uluslararası literatürde yeterince çalışma bulunmaması dolayısıyla Türkiye'de kullanılmakta olan ders kitaplarının türev kavramını ele alması bakımından analiz edilmesi araştırmaya değer görünmektedir (Bingolbali, 2008). Bu analiz sonucunda elde edilen bulgular daha nitelikli ders kitaplarının yazılmasına ve öğretmenlerin derslerini yönlendirebilecek daha nitelikli kaynakların ortaya çıkmasına rehberlik edebilir. Bu çalışmada ilk olarak türev kavramının değişim oranı yorumunun Thompson'un $(1994,2011)$ nicel muhakeme teorisi perspektifinden kavramsal analizi yapılmıştır. Bu kavramsal analiz neticesinde türev kavramının öğrenimi ve öğretiminde önemli noktalar ve temel prensipler belirlenmiştir. Sonrasında bu kavramsal analiz prensipleri bir teorik çerçeve olarak kullanılarak Talim Terbiye Kurulu (TTKB) tarafından onaylanmış ve hâlihazırda 
Türkiye'de Milli Eğitim Bakanlığı (MEB) öğretim programına tabi okullarda okutulan matematik ders kitapları türev konusu ile sınırlı olarak incelenmiştir. Bu çalışmaya ders kitaplarının incelenmesi boyutunda yön veren araştırma soruları şunlardır:

- Ders kitaplarında türev kavramı ve türevin değişim oranı (hızı) yorumu nasıl ele alınmaktadır?

- Ders kitaplarında türevin değişim oranı (hızı) yorumu ile ilgili ne tür gerçek hayat bağlamlarına yer verilmektedir?

Ders kitaplarında türevin değişim oranı (hızı) yorumuna yönelik kovaryasyon ve nispi büyüklük fikirleri nasıl vurgulanmaktadır?

\section{DEĞISŞIM ORANI ÜZERİNE KAVRAMSAL BİR ANALİZ}

Türev kavramının anlamı (i) teğet doğrusunun eğimi, (ii) anlık değişim oranı, (iii) farkların oranının limiti $\lim _{h \rightarrow 0} \frac{f(x+h)-f(x)}{h}$ ) ve (iv) hız olmak üzere dört farklı bağlam ve yorumlama ile sunulabilmektedir (Zandieh, 2000; Zandieh ve Knapp, 2006). Problemin sunulduğu bağlama veya kullanılan gösterimlere bağlı olarak bu yorumlamalardan bir veya birkaçı daha ön plana çıkabilmektedir (Weber ve Dorko, 2014). Örneğin grafik gösterimi ile sunulan bir bağlamda eğim ve farkların oranı fikri ön planda iken, kinematik bağlamında hız yorumu daha görünür olmaktadır. Bu bölümde türevin değişim oranı yorumunun kavramsal olarak ne anlama geldiği, sağlam bir değişim oranı bilgisinin tarifi Thompson'un (1994; 2011) nicel muhakeme teorik çerçevesinden detaylı olarak açıklanacaktır.

\section{Nicel Muhakeme Perspektifinden Değişim Oranı Kavramı}

Nicel muhakeme Thompson $(1994 ; 2011)$ tarafından geliştirilen ve gerçek hayat bağlamlarında matematiksel fikirlerinin ve kavramların anlamlarını derinlemesine inceleyen bir teorik çerçevedir. Nicel muhakeme teorik çerçevesine göre, matematiksel bir ana fikrin gerçek hayat bağlamında anlamlandırılması (i) bir cisim veya nesnenin varlığı, (ii) bu cisme ait bir özellik, (iii) uygun bir birim ve (iii) bu özelliğin nicelleştirilmesi (sayısal bir değer olarak ifade edilmesi) sonucunda gerçekleşebilir (Thompson, 1994). Örneğin hareket halindeki bir aracı düşünelim. Burada araç bir cisimdir. Bu cismin özelliği hareket etmesi, yani bir hızının olmasıdır. Aracın hızının bir özellik olarak algılanması, bunun nicel (sayısal) bir değer olarak ölçülebilmesi fikrini doğurmakta olup bunun için matematiksel işlemlere gereksinim duyulmaktadır. $\mathrm{Bu}$ örnekte aracın hız özelliği bölme işlemi kullanılarak farkların oranı olarak ölçülmektedir.

Nicel muhakeme yaklaşımına göre değişim oranı "iki nicelikteki değişimlerin çarpımsal kıyaslaması sonucunda elde edilen yeni bir nicelik" olarak ifade edilmekte ve bu bir nicel işlem olarak adlandırılmaktadır (Thompson, 2011, s.17). Çarpımsal kıyaslama (Oran) için ise bölme aritmetik işlemi kullanılmaktadır. Bölme işleminin kullanılması bu kavramı kolay hale getirmez zira bölme işleminin kullanılabileceği binlerce farklı gerçek 
hayat durumu bulunabilir. Burada temel zorluk, değişim oranı fikrinin "iki değişkendeki eş zamanlı değişimlerin çarpımsal (nispi) oranı" şeklinde algılanabilmesi ve bunun için doğru aritmetik işlemin seçilebilmesidir. Değişim oranı iki nicelikteki değişimlerin çarpımsal kıyaslaması sonucunda elde edildiği için soyut ve doğrudan ölçülemeyen yeni bir niceliktir (Schwartz, 1988). Değişim oranının bir nicelik olarak ölçülebilmesi birlikte değişen niceliklerin (nicelik-1 ve nicelik-2) değişim miktarlarının oranı alınarak dolaylı bir ölçüm içermektedir (Stroup, 2002; Thompson, 1994). Değişim oranının yeni bir nicelik olarak algılanabilmesi için başlangıçtaki iki niceliğin ve bu iki nicelik ile elde edilen üçüncü niceliğin $\left(x, y, \frac{\Delta y}{\Delta x}\right)$ bir bütün olarak görüldüğü bir bilişsel yapıya ihtiyaç vardır. Bir önceki örnekte bahsettiğimiz hız kavramı, yol ve zaman nicelikleri kullanılarak elde edilmiş olan yeni ve soyut bir nicelik olup bu niceliğin doğru anlaşılabilmesi bu üç niceliğin (Yol, Zaman, Yol/Zaman) bütüncül olarak algılandığı bir bilişsel yapıya sahip olmayı gerektirmektedir (Thompson, 2011). Nicel muhakeme yaklaşımına göre güçlü bir türev veya değişim oranı kavramı bilgisi birlikte değişen iki niceliğin değişimlerinin nispi (oransal) büyüklüğü (relative size) yorumunu gerektirmektedir (Byerley ve Thompson, 2017). Burada nispi büyüklük birlikte değişen iki nicelikten elde edilmiş üçüncü ve soyut niceliği temsil etmektedir. Değişim oranının nispi büyüklük olarak anlamı ise, bağımsız değişkendeki herhangi bir miktar değişime karşılık bağımlı değişkendeki değişimin bunun kaç katı olacağıdır.

Örneğin, $V(h)=5 h^{2}$ bir kabın içerisindeki yüksekliğe (m) bağlı olarak suyun hacmini (lt) veren bir fonksiyon olsun. $V(2)=20$ (lt) ve $V^{l}(h)=10 h \Rightarrow V^{l}(2)=20 \quad$ (lt/m) değerleri elde edilmektedir. $V^{l}(2)=20(\mathrm{lt} / \mathrm{m})$ ifadesinin nispi büyüklük olarak anlamı $h=2 \mathrm{~m}$ anında, yükseklik değişkenindeki herhangi bir miktar değişimin 20 katının hacimde meydana geleceğidir. Yani, $h=2 m$ anında, yükseklik $0,03 m$ değişirse (artarsa) hacmin $0,6 l t$ değişeceği (artacağı) şeklinde yorumlanır ki bu da $V(2,03) \approx 20,6$ yorumunu beraberinde getirmektedir. Anlık değişim oranı sonsuz küçüklükte değişimler için geçerli olduğundan $V(2,03) \approx 20,6$ litre sonucu $V(2,03)$ 'ün gerçek değeri olmayıp, $h=2 m$ anındaki değişim oranı kullanılarak elde edilmiş tahmini bir değerdir. Aynı fonksiyon üzerinde bir başka örnek Şekil-1'de verilmiştir. 


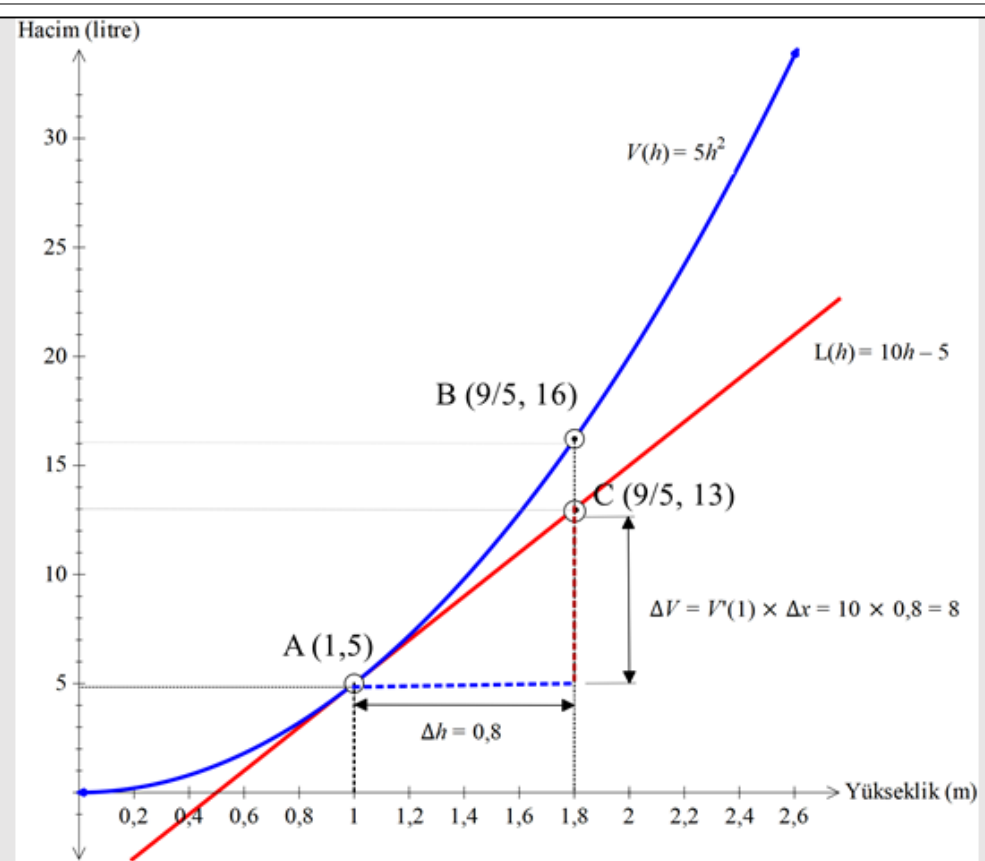

Nispi büyüklük:

$$
\begin{aligned}
& \frac{\Delta V}{\Delta h}=m \Rightarrow \Delta V=m \cdot \Delta h \\
& \frac{d V}{d h}=m \Rightarrow d V=m \cdot d h
\end{aligned}
$$

$V^{1}(1)=10($ litre/m) ifadesinin anlamı, $\mathrm{h}=1$ metre olduğu anda, $h$ 'in herhangi bir miktar değișiminin 10 katı kadar değișimin $V$ 'de meydana geleceğidir. Örneğin $h$ değișkeni 0,8 metre arttığında $V$ değişkeni bunun 10 katı kadar (8 litre) artacaktır. Bu durumda $V(1+0,8) \approx 5+8=13$ litre sonucu elde edilir.

Bu noktada fonksiyonun gerçek değerinin ise $V(1,8)=16$ litre olduğu grafikte görülmektedir.

Şekil 1. Değişim oranının "nispi büyüklük" olarak anlamı

Yukarıdaki örneklerde yükseklikteki 0,03 veya 0,8 metrelik değişimler sonsuz küçük değişimin yanında çok büyük değerler olduğundan farkların oranının burada ortalama değişim oranı anlamına geldiği unutulmamalıdır. Yine de türevin değişim oranı yorumu bir fonksiyonun belli bir nokta civarında alacağı değerin yaklaşık değerini hesaplamak için kullanılabileceği ve bu fikrin kalkülüs kitaplarında doğrusal yaklaşım olarak ele alındığı görülmektedir (bkz. Şekil-2). 


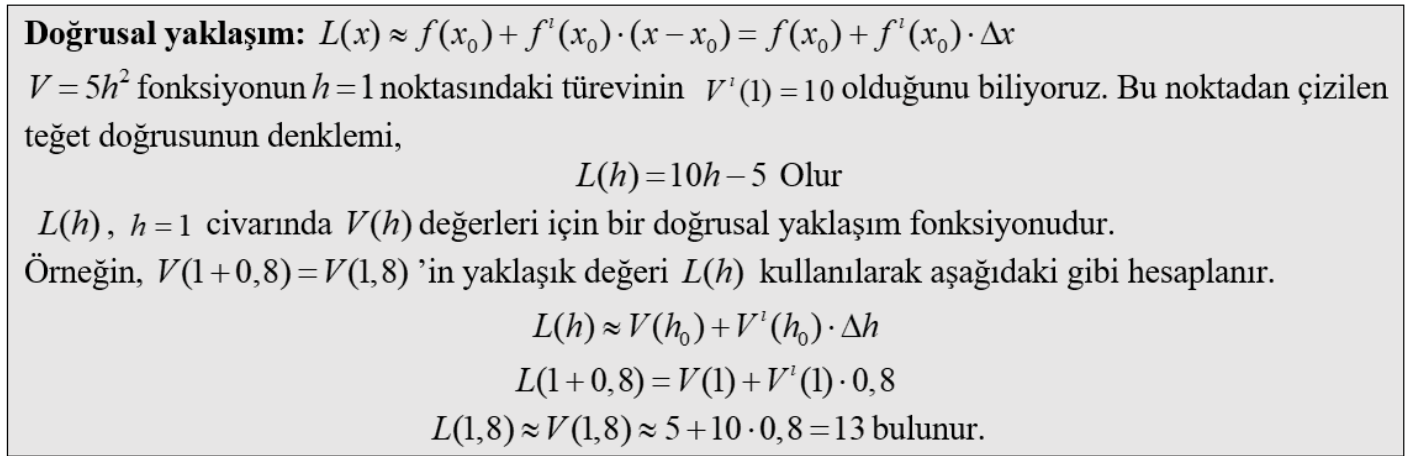

Şekil 2. Nispi büyüklük fikrinin doğrusal yaklaşım ile ilişkilendirilmesi

Türevin ekonomide marjinal-maliyet (bir birim daha fazla ürün üretmek için gereken maliyet) veya marjinal-kar gibi yorumları, aslında tam olarak doğrusal yaklaşım fikrinin bir uygulaması olup, dolayısıyla hata payı içermektedir. Türevin değişim oranı yorumlamasında yaygın olarak kullanılan "birim yükseklikte meydana gelen hacim değişimi" veya "birim zamanda alınan yol" gibi sözel açıklamalar nispi büyüklüguün bağımsız değişkendeki farklarını sadece 1'er birime sabitlenerek oluşturulan özel bir durumudur. "Birim yükseklikteki hacim" güçlü bir fikir olmasına karşın, ayrık düşünme içermesinden dolayı değişim oranının bir tür oran olarak değil de, bağımlı değişkende meydana gelen değişim miktarı olarak algılanmasına sebebiyet verdiği görülmektedir (Cooney ve diğerleri, 2010).

\section{Kovaryasyonel düşünme neden önemli?}

Türev kavramının farkların oranı, değişim oranı, hız ve hatta eğim yorumlarının nispi büyüklük olarak algılanabilmesi için ileri düzey kovaryasyonel düşünme becerisinin gerekliliği birçok çalışmada ortaya konulmaktadır (örn., Carlson vd., 2002; Confrey ve Smith, 1994; Kertil, 2020; Thompson, 1994; Thompson ve Carlson, 2017). Kovaryasyonel düşünme iki niceliğin eş zamanlı ve dinamik değişimini aynı anda görebilme ve koordine edebilmeyi gerektirmektedir. Kertil ve arkadaşları da (2019) ileri düzey kovaryasyonel düşünme becerisi ile sağlam bir değişim oranı bilgisi arasında çift yönlü bir ilişki olduğunu ortaya koymaktadır. Nitekim değişim oranı ile ilgili öğrenci ve öğretmen zorluklarının temel kaynağının kovaryasyonel düşünebilme yeterlikleri ile ilgili olduğu birçok araştırmada raporlanmaktadır (Byerley ve Thompson, 2017; Thompson, 1994; Thompson vd., 2017; Zandieh ve Knapp, 2006).

Thompson ve Carlson (2017) tarafından geliştirilen kavramsal çerçevede kovaryasyonel düşünmenin en üst seviyeleri sırasıyla kesikli-sürekli kovaryasyon ve düzgün (kesiksiz) sürekli kovaryasyon olarak ifade edilmektedir. Kesikli sürekli kovaryasyon iki değişkenin birlikte değişimi üzerine bağımsız değişkendeki değişimi eşit ve küçük aralıklara bölerek kesik kesik düşünmeyi ifade ederken, düzgün (kesiksiz) sürekli kovaryasyon iki değişkenin birlikte değişimini küçük aralıklara bölmeden sürekli ve kesiksiz olarak düşünebilmeyi ifade etmektedir. Örneğin, hızı 100 km/saat olan bir araç için, her bir saatte $100 \mathrm{~km}$ yol alacağını veya her iki saatlik dilimlerde 200'er km yol 
alacağını düşünmek kesikli sürekli kovaryasyonel düşünme içermektedir. Aynı araç için zaman aralıkları istenildiği kadar küçük alınsa bile (örn. 0,005'er saniye, 2'şer dakika vb.) yol ile zaman değişkenlerinin birlikte değişimlerinin veya değişim oranlarının aynı kalacağını düşünebilme kesiksiz sürekli kovaryasyon seviyesini göstermektedir. Yine, hacim-yükseklik bağlamında değişim oranının "birim yükseklikteki hacim değişimi" yorumu kesikli sürekli kovaryasyonel düşünmenin bir göstergesi iken, nispi büyüklük yorumu (yükseklikteki herhangi bir miktar değişimin x katı kadar değişimin hacimde meydana geleceği) sürekli düzgün kovaryasyonel düşünme seviyesine karşılık gelmektedir. Değişim oranı kavramının bir değişkende meydana gelen değişim miktarı olarak algılanması aslında daha düşük seviyelerde bir kovaryasyonel düşünme becerisine sahip olmaktan kaynaklanmaktadır. Dolayısıyla, türev kavramının değişim oranı yorumuyla birlikte doğru anlaşılabilmesi için ileri düzey kovaryasyonel düşünme becerileri önemli gereksinimlerden birisidir.

Genel olarak özetlemek gerekirse, nicel muhakame bakış açısıyla ders kitabında, öncelikle türev kavramının, içerisinde gömülü olan değişkenlerin gerçek hayat durumunda birer nicelik olarak algılanmasını kolaylaştıracak vurgulamaların yapılması gerekmektedir. Bunun için de ilk olarak farklı gerçek hayat bağlamlarının kullanılması, yani bağlam çeşitliliği çok önemlidir (Byerley ve Thompson, 2017; Jones, 2017; Mkhatshwa, 2018). İkinci olarak, niceliklerin birimleriyle birlikte kullanılması ve yorumlanması gereklidir (Thompson, 1994). Üçüncü olarak ise değişim oranını iki farklı nicelik ve bu niceliklerin birlikte değişimi sonucu ortaya çıkan üçüncü ve soyut nicelik olarak yorumlaması için kovaryasyon (birlikte değişim) fikri ve son olarak ta nispi büyüklük fikrinin vurgulanması gerekmektedir (Byerley ve Thompson, 2017).

\section{DEĞiş̧iM ORANI (HIZI) KAVRAMININ ÖĞRETIMİ VE ÖĞRENIMİ: LİTERATÜR TARAMASI}

Literatür incelendiğinde, değişim oranı (hızı) kavramının anlaşılmasına ilişkin ciddi problemler görülmekte olup, öğretmen ve öğrencilerin türev kavramını farklı gerçek hayat bağlamlarında değişim oranı olarak yorumlama ve anlamlandırmada ortak bazı zorluklar yaşadıkları görülmektedir (Byerley, 2019; Byerley ve Thompson, 2017; Gravemeijer ve Doorman, 1999; Herbert ve Pierce, 2012; Mkhatshwa, 2016; Mkhatshwa ve Doerr, 2018). İlk olarak değişim oranı kavramının bir oran olarak değil de, tek bir nicelikte meydana gelen değişim miktarı olarak anlaşılması en sık raporlanan durumdur (Byerley ve Thompson, 2017; Jones, 2017; Kertil, 2014; Lobato ve diğerleri, 2012; Rowland ve Jovanoski, 2004; Thompson, 1994). Örneğin, $f(t)=V$ ifadesi sabit debiyle doldurulan bir kap içerisinde biriken suyun hacminin (ml) zamana bağlı (saniye) olarak değişimini veren bir fonksiyon olsun. $\mathrm{Bu}$ bağlamda $\frac{d}{d t} f(3)=f^{\imath}(3)=0,2$ sembolik ifadesinin verilen bağlamda ne anlama geldiği sorulduğunda, üçüncü saniyede suyun hacminin 0,2 mililitre değiştiği (arttığı) şeklindeki bir cevap türevin sadece hacim değişkeninde meydana gelen "değişim miktarı" olarak yorumlandığının bir 
göstergesidir. $\mathrm{Bu}$ yorum farklı gerçek hayat bağlamlarında bir noktadaki türevin yorumuna ilişkin sorulara öğrencilerin verdiği en tipik ve yaygın cevaplardan birisidir (Bingolbali, 2008; Kertil, 2014; Thompson, 1994). Benzer şekilde öğrencilerin hareket bağlamında da hız kavramını iki değişkendeki değişimlerin oranı olarak algılamakta zorlandıkları ve bir saatte alınan yol miktarı olarak yorumlandıkları gözlemlenmektedir (Kertil, 2014; Thompson, 1994). Yine, Mkhatshwa (2018) işletme bölümünde kalkülüs dersini alan öğrencilerle yaptığı çalışmada türevin marjinal maliyet ve marjinal kar anlamlarını bağımlı değişkende meydana gelen değişim miktarı olarak gördüklerini raporlamıştır. Cooney ve diğerlerine (2010) göre, bu sorun bağımsız değişkendeki değişimi bir birim olarak sabitleyip bağımlı değişkendeki değişme odaklanmanın getirdiği doğal bir sonuçtur. Örneğin hız kavramını "1 saatte alınan yol miktarı" veya benzer şekilde marjinal maliyeti "bir ürün daha üretildiğinde maliyetteki değişim" olarak tanımlamak yanlış olmasa da türevin değişim oranı olarak anlaşılmasının önünde bir engel oluşturulabilmektedir. Bu düşünme biçimi yanlış olmamakla birlikte ayrık düşünme içerdiğinden (bağımız değişkendeki 1 birim değişime karşılık bağımsız değişkenin ne kadar değiştiği) değişim oranı fikrini tam olarak desteklememektedir (Thompson, 1994). Yani $\frac{\Delta y}{\Delta x}$ oranında $\Delta x=1$ olarak düşünüldüğ̈unde $\frac{\Delta y}{\Delta x}$ (oran) ile $\Delta y$ (miktar) sonuçları birimleri aynı olmasa bile aynı nümerik değere sahip olmaktadır. Yine Cooney ve diğerleri (2010) bu durumun önüne geçmek için bağımsız değişkendeki değişimleri sistemli olarak 1 birim yapmak yerine, örneğin 0,2 birim, 0,003 birim, 5 birim gibi 1'den farklı değerler vererek öğrencileri orantısal düşünmeye zorlamanın öneminden bahsetmektedir.

Değişim oranı kavramının anlaşılması ile ilgili bir diğer zorluğun "değişim oranı" ifadesinin dil olarak anlaşılmaması ile ilişkili olabileceği raporlanmaktadır (örn. Bezuidenhout, 1998; de Beer vd., 2015; White ve Mitchelmore, 1996). Öğrencilere bir fonksiyonun ortalama değişim oranı sorulduğunda bunun ne anlama geldiğini bilmediklerinden dolayı fonksiyonun aritmetik ortalamasını alma gibi bazı ilgisiz işlemeler yaptığı görülmektedir. Bu durum Türkiye'de öğrenim gören öğrencilerde de gözlemlenmiştir (Bingolbali, 2008; Kertil, 2014; Kertil vd., 2017). White ve Mitchelmore'a (1996) göre öğrencilerin $\frac{d y}{d x}$ sembolik ifadesinde verilen harflerin bağlamda hangi niceliklere karşıllı geldiğini düşünmemeleri bunun bir sebebi olabilir. Farklı dillerde "değişim oranı" ifadesinin doğru şekilde anlaşlamaması dil bilimsel bir problem olabileceği gibi, ders kitapları ve diğer kaynaklarda bu kavramın yeterince vurgulanmamasının doğal bir sonucu olarak da yorumlanabilmektedir (Bingolbali, 2008).

Öte yandan, değişim oranı kavramın müfredat kaynaklarında yeterince vurgulanmadığı veya sadece fizik alanındaki hareket (yol-zaman, hız ve ivme) bağlamıyla kısıtlı olarak ele alındığı gözlemlenmektedir (Berry ve Nyman, 2003; Jones, 2017; Doorman ve Gravemeijer, 2009; Weber ve Dorko, 2014). Türev kavramının öğretiminde sadece kinematik (hareket) bağlamının kullanılması öğrencilerin değişim oranı kavramını 
başka gerçek hayat bağlamlarında anlamlandırmakta zorlanmalarına sebebiyet vermektedir (Bektaşlı ve Çakmaklı, 2011; Berry ve Nyman, 2003; Jones, 2017; Mkhatshwa, 2016, 2018; Mkhatshwa ve Doerr, 2018; Wilhelm ve Confrey, 2003; Zandieh ve Knapp, 2006). Ayrıca öğrencilerin erken yaşlardan itibaren hız kavramına aşina olmaları sebebiyle bu kavram üzerine derinlemesine düşünme ihtiyacı hissetmemeleri ve dolayısıyla değişim oranı fikrini kaçırmaları söz konusudur (Bezuidenhout, 1998; Thompson, 1994). Ayrıca azalan fonksiyonlarda negatif işaretli olmasından kaynaklı (Ärlebäck vd., 2013; Ärlebäck ve Doerr, 2018), üstel büyüme içeren ve doğrusal olmayan fonksiyonlarda karşılaşılan bazı problemler (Confrey ve Smith, 1994; Ellis vd., 2015; Stroup, 2002), değişim oranına ilişkin olarak literatürde raporlanan diğer bazı öğrenci zorluklarıdır.

\section{YÖNTEM}

Bu çalışmada ders kitaplarının analiz edilmesi sürecinde nitel araştırma yöntemlerinden doküman incelemesi yöntemi kullanılmıştır. Dokuman incelemesi, araştırılması hedeflenen konu hakkında bilgi içeren materyallerin analizini kapsamaktadır (Yıldırım ve Şimşek, 2011). Ders kitapları, öğretmen ve öğrencilere rehberlik etmesi bakımından nitel araştırmalar açısından her zaman incelemeye değer kaynaklardır.

\section{Veri kaynağı olarak ders kitaplarının seçimi}

Türev konusu ve kavramı matematik öğretim programında 12. sınıf düzeyinde yer alan bir alt öğrenme alanıdır. Bu çalışmada türev kavramının değişim oranı yorumu üzerine odaklanıldığı için doğal olarak incelenecek olan kitaplar 12. sınıf düzeyi matematik ders kitaplarının incelenmesine karar verilmiştir. Hâlihazırda Talim Terbiye Kurulu onayından geçen ve şu anda aktif olarak okutulmakta olan kitapların tamamı (üç ders kitabı) incelenmektedir.

- Ders Kitabı-1 (Kemancı, Büyükokutan, Çelik ve Kemancı, 2020),

- Ders Kitabı-2 (Emin, Gerboğa, Güneş ve Kayacıer, 2020),

- Ders Kitabi-3 (Altun, 2018).

MEB (2018) lise matematik öğretim programında ve ders kitaplarında Türev alt öğrenme alanının (i) limit ve süreklilik, (ii) anlık değişim oranı ve türev ile (iii) türevin uygulamaları konularından oluşmaktadır. Bu çalışma kapsamında türev kavramının değişim oranı yorumu üzerine odaklanıldığı için ders kitapları incelenirken türev alt öğrenme alanının ilk konusu olan "Limit ve Süreklilik" hariç tutulmuştur.

\section{Veri analizi}

Nicel muhakeme bakış açısıyla türevin değişim oranı yorumuna ilişkin ders kitaplarının analizinde kullanılacak analiz temaları olarak (i) bağlam çeşitliliği, (ii) birimlerin kullanımı ve yorumlanması, (iii) kovrayasyon fikri, ve (iv) nispi büyüklük fikri belirlenmiştir. 
(i) Bağlam çeşitliliği: Bu analiz teması altında ders kitaplarında kullanılan gerçek hayat bağlamlarının neler olduğu ve çeşitliliği (örn. Kinematik, ekonomi, alanhacim vb.) analiz edilmiștir.

(ii) Birimlerin kullanımı ve yorumlanması: $\mathrm{Bu}$ tema altında türev kavramının "ortalama" veya "anlık değişim oranı" olarak bağlam içerisinde bulunan niceliklerin birimleriyle beraber yorumlanıp youmlanmadığı ve nasıl yorumlandığı analiz edilmiştir.

(iii) Kovaryasyon fikri: Bu tema altında ders kitaplarında yer verilen değişim oranı yorumlamalarında iki niceliğin eş zamanlı olarak birlikte değiştiği fikrinin (birlikte değişim) vurgulanıp vurgulanmadığı analiz edilmiştir. Öğrencileri iki değişkenin birlikte, dinamik ve eş zamanlı değişimine (kovaryasyonel düşünmeye) yönlendirebilmek için bağımsız değişkenin zaman olmadığı, doğrudan dinamik olarak gözlemlenebilir olgular kullanımı önerilmektedir. Örneğin, zamana bağlı yol denildiğinde zaman soyut bir nicelik olduğundan kovaryasyon fikri bariz şekilde ortaya çıkmaz. Ancak, su ile doldurulan bir depoda yüksekliğe bağlı olarak hacim doğrudan ve dinamik olarak gözlemlenebilir olduğundan kovaryasyon fikrini daha görünür hale getirmekte olup öğrenciyi kovaryasyonel düşünmeye yönlendirme potansiyeli daha yüksektir. $\mathrm{Bu}$ çalışma kapsamında incelenen ders kitaplarında kullanılan çözümlü örnekler, etkinlikler ve değerlendirme sorularında kovaryasyon fikrini doğrudan vurgulayan veya daha aşikâr yapabilme potansiyeli olan içerikler incelenmiştir. Bağımsız değişkenin zaman olduğu içeriklerde de kovaryasyon fikrinin yapılan yorumlamalarda vurgulanıp vurgulanmadığı da incelenmiştir.

(iv) Nispi büyüklük fikri: Bu tema altında, ders kitaplarında bağımlı değişkendeki değişimin bağımsız değişkendeki değişimin kaç katı olduğu veya doğrusal yaklaşım fikirlerinin vurgulanıp vurgulanmadığı analiz edilmiştir.

\section{BULGULAR}

Bulgular her bir ders kitabı için (i) bağlam çeşitliliği, (ii) birimlerin kullanımı ve yorumlanması, (iii) kovaryasyon fikri ve nispi büyüklük fikri olmak üzere üç ayrı başlık altında raporlanmaktadır.

\section{Bağlam çeşitliliği}

Her bir ders kitabının türev alt öğrenme içerikleri, konu girişlerinde ders anlatımının yapıldığı kısımlar da dâhil olmak üzere, çözümlü örneklerin, etkinliklerin, projelerin ve bölüm sonu değerlendirme sorularının içerdiği bağlamlar bakımından analiz edilmiştir. Tamamen cebirsel ve herhangi bir bağlam içermeyen çözümlü örnekler, sorular ve diğer içerikler de frekans dağılımı olarak tabloya yansıtılmıştır. 
Tablo 1

Ders kitaplarında Türev konu içeriğinin bağlam çeșitliliği bakımından analizi

\begin{tabular}{lccc}
\hline & $\begin{array}{c}\text { Ders Kitabı-1 } \\
\mathrm{f}(\%)\end{array}$ & $\begin{array}{c}\text { Ders Kitabı-2 } \\
\mathrm{f}(\%)\end{array}$ & $\begin{array}{c}\text { Ders Kitabı-3 } \\
\mathrm{f}(\%)\end{array}$ \\
\hline Hareket bağlamı (Kinematik) & $12(\% 7,5)$ & $12(\% 6)$ & $9(\% 5)$ \\
Teğet doğrusunun eğimi & $10(\% 6)$ & $13(\% 6)$ & $8(\% 4,5)$ \\
Ekonomi (kar-zarar, maliyet) & $3(\% 2)$ & $5(\% 2,5)$ & $1(\% 0,6)$ \\
Nüfus-Popülasyon & $1(\% 0,6)$ & - & - \\
Uzunluk-Alan-Hacim & $10(\% 6)$ & $15(\% 7,3)$ & $17(\% 9,4)$ \\
Herhangi bir bağlam içermeyen & $125(\% 78)$ & $160(\% 78)$ & $146(\% 81)$ \\
\hline Toplam & $161(\% 100)$ & $205(\% 100)$ & $181(\% 100)$ \\
\hline
\end{tabular}

Not: Kitap içeriklerinin tamamı (değerlendirme soruları da dâhil) incelenmiştir.

Her üç kitapta da "türevin değişim oranı yorumu" ve "türev ve uygulamaları" konuları cebirsel (herhangi bir bağlam içermeyen) ağırlıklı olarak ele alındığı görülmektedir. Türevin değişim oranı anlamı genellikle kinematik bağlamında hız veya ivme kavramları ile açıklanmaktadır. Cebirsel ve grafik gösterimlerle destekli olarak teğet doğrusunun eğimi de en sık vurgulanan yorumlardan bir diğeridir. Türevin değişim oranı yorumlaması için kinematik dışı gerçek hayat bağlamlarının nadiren kullanıldığı görülmektedir. Ekonomi ve uzunluk-alan-hacim bağlamlarının genellikle türevin uygulamaları konusunda optimizasyon problemlerinde kullanıldığı görülmektedir. Optimizasyon problemlerinde türevin ne anlama geldiğinin yorumlanmasından ziyade kritik, maksimum, minimum ve büküm noktalarının ve artan-azalan aralıkların belirlenmesi şeklinde daha çok prosedür ağırlıklı uygulamalar içermektedir.

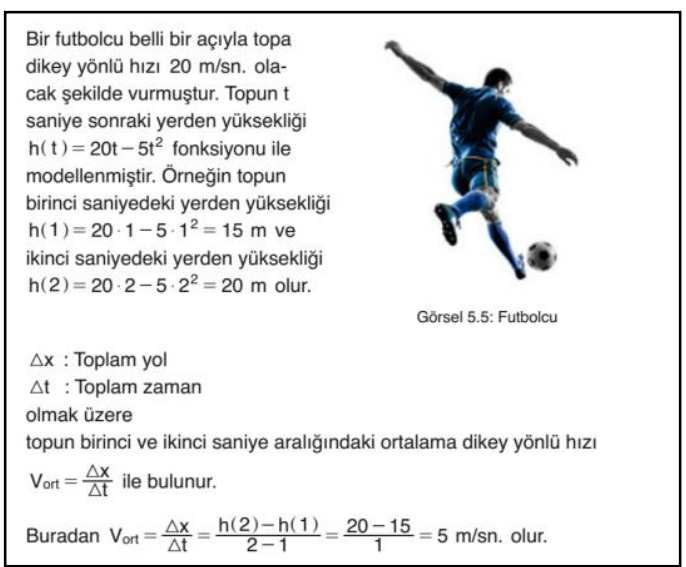

Şekil 3. Ders Kitabı-1'de türevin değișim oranı yorumuna giriş (s. 266)

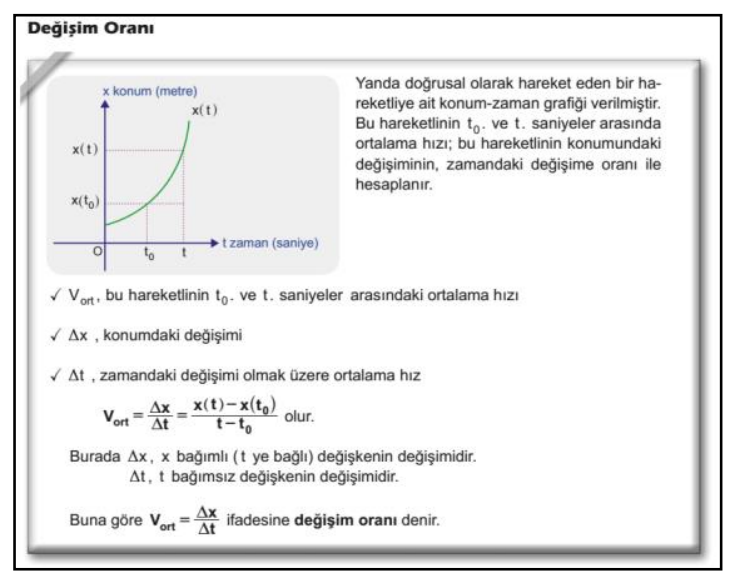

Şekil 4. Ders Kitabı-2'de türevin değişim oranı yorumuna giriş (s. 213) 
Şekil 3 ve Şekil 4'te görüldüğü üzere Ders Kitabı-1 ve Ders Kitabı-2'de türevin değişim oranı yorumuna kinematik bağlamı "ortalama hız" kavramı ile yapılmıştır. Ders Kitabı1'de yer alan çözümlü örneklerde de yine kinematik bağlamının kullanıldığı görülmektedir. Konu sonu değerlendirme soruları incelendiğinde ise doğrudan türevin değişim oranı yorumuna yönelik olarak üç adet ekonomi bağlamından (marjinal gider, marjinal gelir ve marjinal kar) soru kullanıldığı görülmektedir. Fakat konu anlatımı kısmında ekonomi bağlamından çözümlü örnek veya etkinlik kullanılmadığı ve ekonomi bağlamında türevin anlamı üzerine bir yorumlamanın yapılmadı̆̆ı görülmektedir. Ders Kitabı-2'de ise değişim oranına yönelik hareket bağlamı haricinde bir bağlam kullanılmadığı gözlemlenmiştir.

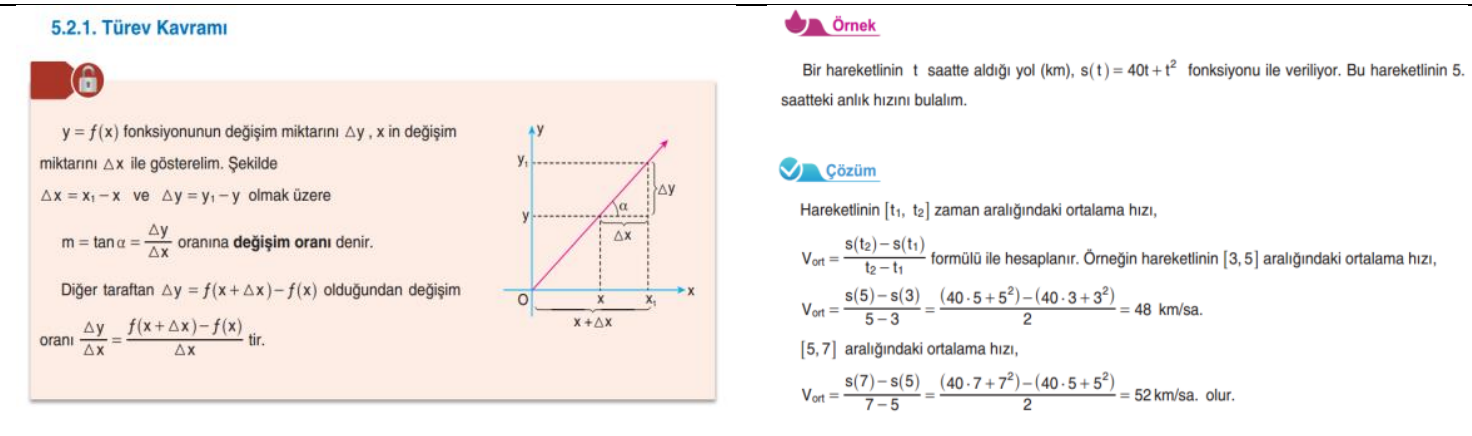

Şekil 5. Ders Kitabı-3'te değişim oranı ve türev konusuna giriş (s. 179-180)

Ders Kitabı-3 incelendiğinde ise değişim oranı kavramına bir gerçek hayat bağlamı kullanılmadan, grafik gösterim üzerinde eğim ve farkların oranı vurgusu ile giriş yapılmış ve hemen ardından yine kinematik bağlamından bir örnek kullanılmıştır. Sonraki çözümlü örneklerde ise kinematik bağlamlarının haricinde sadece bir tane ekonomi bağlamından (gidilen yola bağlı yakıt gideri) bir örnek kullanılmıştır. Genel olarak değerlendirildiğinde ise her üç kitabın içeriğinin türevin değişim oranı yorumu bakımından gerçek hayat bağlam çeşitliliği bakımından yeterli olduğunu söylemek mümkün görünmemektedir.

\section{Birimlerin vurgulanması ve yorumlanması}

Birimlerin kullanımı ve yorumlanması ile ilgili analizler her üç ders kitabında da bölüm sonu değerlendirme soruları hariç tutularak diğer içerikler sayılarak hesaplanmıştır. 
Tablo 2

Ders kitaplarında Türev konu içeriğinde birimlerin kullanımı ve yorumlanması

\begin{tabular}{lccc}
\hline & $\begin{array}{c}\text { Ders Kitabı-1 } \\
(\mathrm{n}=6) \mathrm{f}(\%)\end{array}$ & $\begin{array}{c}\text { Ders Kitabı-2 } \\
(\mathrm{n}=14) \mathrm{f}(\%)\end{array}$ & $\begin{array}{c}\text { Ders Kitabı-3 } \\
(\mathrm{n}=11) \mathrm{f}(\%)\end{array}$ \\
\hline $\begin{array}{l}\text { Birimlerin eksiksiz ve } \\
\text { doğru kullanımı }\end{array}$ & $6(\% 100)$ & $12(\% 86)$ & $8(\% 73)$ \\
$\begin{array}{l}\text { Birimler kullanılarak } \\
\text { derinlemesine } \\
\text { yorumlama }\end{array}$ & $1(\% 17)$ & $2(\% 14)$ & $3(\% 27)$ \\
$\begin{array}{l}\text { Birim eksik kullanımı } \\
\text { veya kullanılmaması }\end{array}$ & - & $2(\% 14)$ & $11(\% 100)$ \\
\hline \begin{tabular}{l} 
Toplam \\
\hline
\end{tabular} & $6(\% 100)$ & $14(\% 100)$ & $18)$
\end{tabular}

Not: Bu kısımda sadece gerçek hayat bağlamı kullanılan içerikler, değerlendirme soruları hariç tutularak sayılmıştır.

Her üç ders kitabında yer alan bağlamsal problemlerde birimlerin genellikle kullanıldığı fakat derinlemesine yorumlama kısmında eksiklik olduğu görülmektedir. Her üç ders kitabında da çoğunlukla kinematik bağlamından kullanılan örneklerde hız ve ivme gibi özel kavramların birimlerinin doğru ve eksiksiz kullanıldığı fakat optimizasyon problemlerinde bazı örneklerde birimlere dikkat edilmediği görülmektedir. Birimler kullanılarak değişim oranı üzerine sözel yorumlamalar ise her üç kitapta da nadiren yapıldığı, bu yorumlamaların ise sadece kinematik bağlamıyla kısıtlı olduğu ve değişim oranının ilk defa açıklandığı kısımlarda yer verildiği görülmektedir. Örneğin, her üç kitapta da bir aracın anlık hızın $40 \mathrm{~km} / \mathrm{saat}$ olarak bulunduğu bir örnekte, türev olarak bulunan bu sonucun ne anlama geldiğinin birimlerle birlikte sözel veya nümerik olarak yorumunun yeterince vurgulanmadığg görülmektedir. Hareket halindeki bu araç için 40 $\mathrm{km} / \mathrm{saat}$ hızın tam olarak ne anlama geldiği; verilen andaki hızla devam ederse 1 saniyede ya da 5 saniyede yaklaşık ne kadar yol alacağ gibi örneklerle desteklenerek derinlemesine incelenmemektedir. 


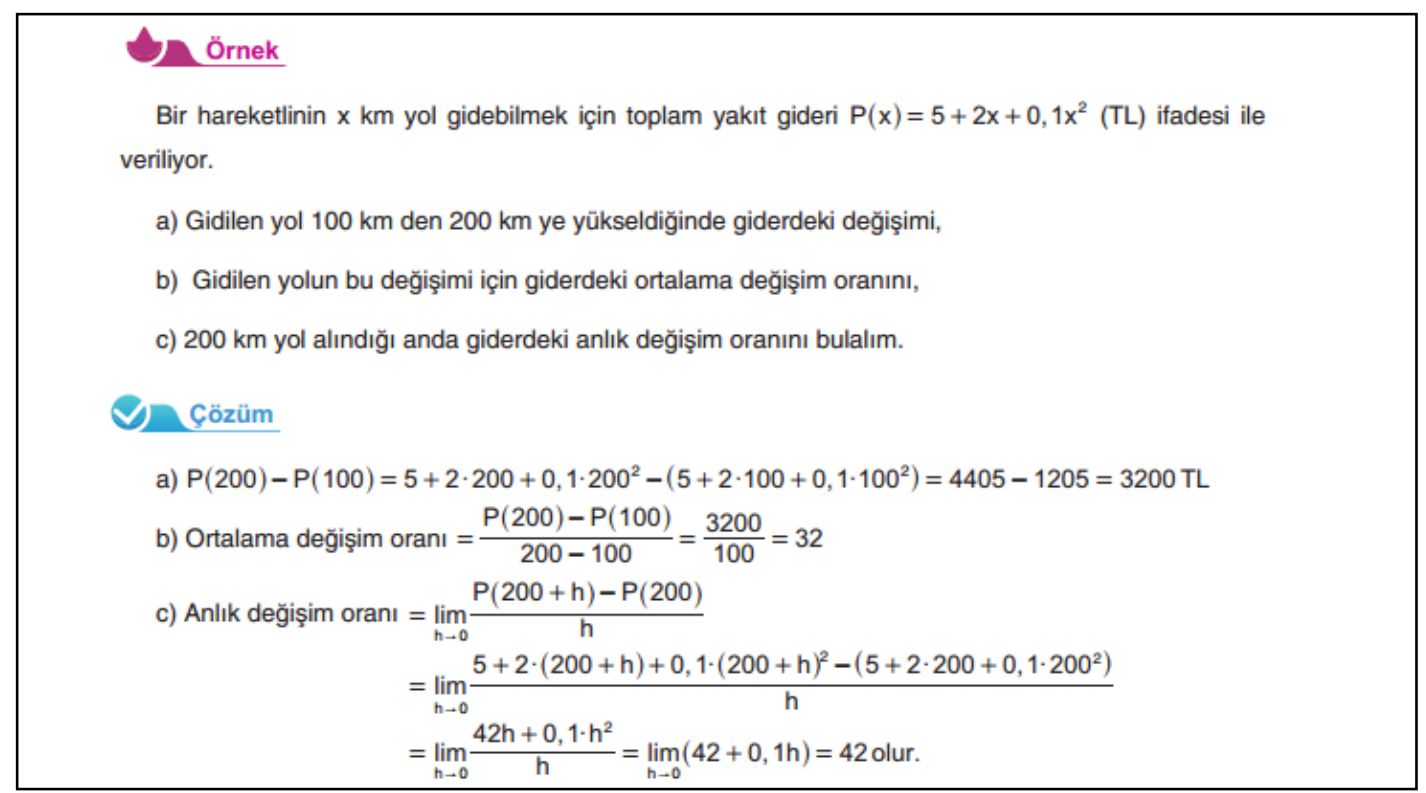

Şekil 6. Ders Kitabı-3'te kullanılan çözümlü bir örnek

Şekil 6'da görülen çözümlü örnekte, bir hareketlinin gittiği yola bağlı olarak yakıt giderini veren bir fonksiyon bağlamında ortalama ve anlık değişim oranları sorulmuştur. Sorunun b ve c şıklarında ortalama değişim oranı ve anlık değişim oranı nümerik değer olarak bulunmuş fakat birimleri belirtilmemiştir. Yukarıdaki örnek, değişim oranı kavramı için kinematik dışından farklı bir bağlam teşkil etmekle beraber, elde edilen nümerik sonucun birimiyle $(\mathrm{TL} / \mathrm{km})$ birlikte verilmemesi ve bunun verilen bağlamda ne anlama geldiğinin yeterince yorumlanmaması ciddi bir sorundur. Örneğin, c şıkkında verilen sonuç 200. km'de değişim oranının 42 TL/km olarak bulunmasını, $1 \mathrm{~km}$ daha yol alırsa yaklaşık 42 TL kadar daha yakıt giderinin oluşacağı gibi yorumlamalar bulunmamaktadır. Nispi büyüklük olarak ise bu durum 200. km'den itibaren gidilecek her x km yolun 42 katı kadar yani, 42x TL kadar daha yakıt gideri oluşturacağı şeklinde yorumlanabilir. Bir kilometre yol gidildiğinde 42 TL ek maliyetin ortaya çıması gerçekte olabilecek bir durum değildir. Aslında, türevin değişim oranı olarak anlamının verilen bağlamdaki değişkenlerle derinlemesine yorumlanması, yukarıdaki örnekte görüldüğü üzere (bkz. Şekil 6), verilen kurgu bağlamın gerçek hayattan ne kadar uzak olduğunu anlamamıza da yardımcı olacaktır. 


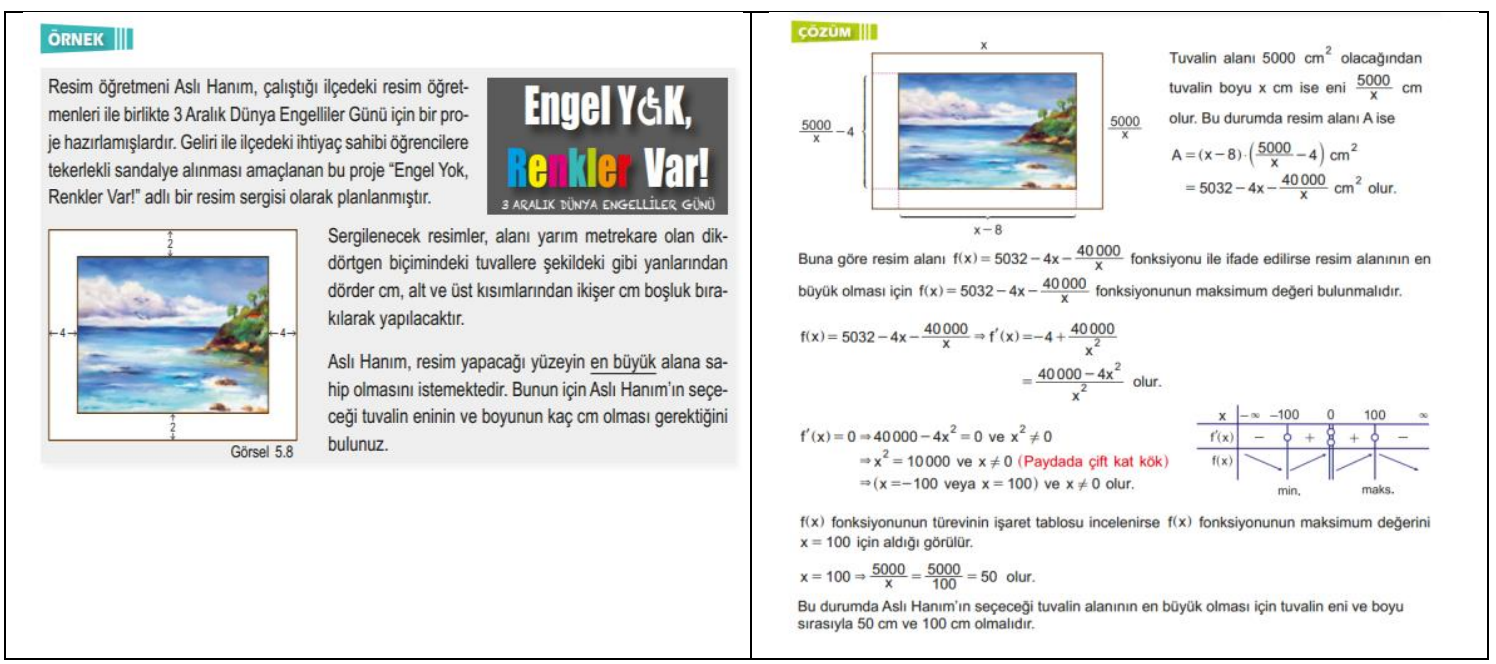

Şekil 7. Ders Kitabı-2'de kullanılan çözümlü bir örnek (s. 280).

Özellikle türevin uygulamaları kısmında kullanılan optimizasyon problemlerinde türev fonksiyonlarının birimleri hemen hemen hiçbir örnekte vurgulanmamış ve kullanılmamıştır. Şekil 7'de en büyük alana sahip bir tuvalin boyutlarını belirlemeye yönelik bir optimizasyon problemi görülmektedir. Tuvalin içerisinde resim yapılacak bölgenin alan fonksiyonu, tuvalin dıştaki kenarının uzunluğuna bağlı olarak elde edilmesine karşın, bunun türevinin biriminin ne olduğu yazılma ihtiyacı hissedilmemiş ve ne anlama geleceği yorumlanmamıştır. Bu durum her üç kitapta da optimizasyon problemlerinde karşımıza çıkmaktadır. Optimizasyon problemlerinde türevin ne anlama geldiğinin yorumlanması bir gereksinim olmamakla birlikte farklı bağlamlarda türevin anlamını vurgulamak için bir firsat olarak kullanılabilir. Burada sadece kritik noktaları belirlemek için birinci türev sıfıra eşitlenerek işlem yapıldığı görülmektedir. Türevin ve türev değerinin sıfır olmasının ne anlama geldiği bağlamsal olarak yorumlanmadığı görülmektedir.

\section{Kovaryasyon ve Nispi Büyüklük Fikri}

Her bir ders kitabı içeriğinde kullanılan çözümlü örnekler, etkinlikler ve değerlendirme sorularında kovaryasyon ve nispi büyüklük fikirlerinin vurgulanıp vurgulanmadığı yönelik analizin betimsel sonucu aşağıda tabloda sunulmaktadır. 
Tablo 3

Ders kitaplarında türev konu içeriğinde kovaryasyon ve nispi büyüklük fikri

\begin{tabular}{lcccc}
\hline & & $\begin{array}{c}\text { Ders Kitabi-1 } \\
(\mathrm{n}=26)\end{array}$ & $\begin{array}{c}\text { Ders Kitabi-2 } \\
(\mathrm{n}=32)\end{array}$ & $\begin{array}{c}\text { Ders Kitabi-3 } \\
(\mathrm{n}=27)\end{array}$ \\
\hline Kovaryasyon fikri & $\begin{array}{l}\text { Potansiyeli } \\
\text { olan içerik } \\
\text { Vurgulama- } \\
\text { yorumlama }\end{array}$ & 0 & $12(\% 35)$ & $13(\% 48)$ \\
Nispi büyüklük fikri & $9(\%)$ & 0 & $1(\% 4)$ \\
\hline Toplam & & $26(\% 100)$ & $32(\% 100)$ & $27(\% 100)$
\end{tabular}

Not: Gerçek hayat bağlamı kullanılan içerikler değerlendirme soruları da dâhil edilerek hesaplanmiştır.

Tablo 3'te görüldügüü üzere, her üç kitapta da çözümlü örnekler, etkinlikler ve değerlendirme sorularında kovaryasyon ve nispi büyüklük fikrini içeren yorumlama ve vurgulamalar bakımından yeterli olmadığı görülmektedir. Ders Kitabı-3'te kinematik bağlamından kullanılan bir örnekte hız ve zaman değerleri tablo verisi olarak radar fikriyle verilerek kovaryasyon (eş zamanl, birlikte değişim) fikriyle bir noktadaki türev değeri yorumlanmıştır. Fakat yine Ders Kitabı-3'te yer alan, Şekil 6'da sunulan örnekte görüldüğü üzere zaman dışında bir bağımsız değişken kullanıldığı ve kovaryasyon ve nispi büyüklük fikirlerinin daha kolay işlenebileceği bir bağlamda (gidilen yola bağlı yakıt gideri) bu vurgu yapılmamıştır.

Her üç kitapta da kovaryasyon fikrini destekleme potansiyeline sahip içerikler bulunmaktadır. Fakat, bu içeriklerin çoğunlukla türevin uygulamaları (optimizasyon, maks-min problemleri) kısmında kullanıldığı görülmektedir. Daha önce de ifade edildiği üzere, optimizasyon problemleri bağlamında türevin daha çok işlemsel olarak (kritik noktaları belirlemek için birinci türevi sıfıra eşitleme, ikinci türevin işaretini inceleme vb.) kullanıldığı, verilen bağlamda türevin ne anlama geldiğinin hiçbir şekilde vurgulanmadığı görülmektedir. Bu nedenle de optimizasyon kısmında kullanılan kenar uzunluğuna bağlı alan, yüksekliğe bağlı hacim, satılan bilet sayısına bağlı elde edilen kar gibi, bağımsız değişken olarak zaman içermeyen, gerçek hayat durumlarında kovaryasyon ve nispi büyüklük fikirlerini vurgulama firsatı heba edilmektedir. Nitekim kenar uzunluğuna bağlı alan veya hacim değişimi gibi durumların dinamik animasyonu GeoGebra, Geometrry Sketchped, Cabri ve Desmos gibi birçok dinamik geometri programlarıyla kolaylıkla yapılabilmektedir. Bu animasyonlar öğrencilerin değişkenlerin dinamik ve eş zamanlı değişimini veren kovaryasyon fikrini geliştireceği gibi, dinamik değişim olarak fonksiyon ve nispi büyüklük olarak değişim oranı fikirlerine katkı sunmaktadır. Teknoloji kullanımını potansiyel olarak taşıyan örneklerden biri Şekil 8'de sunulmuştur. 


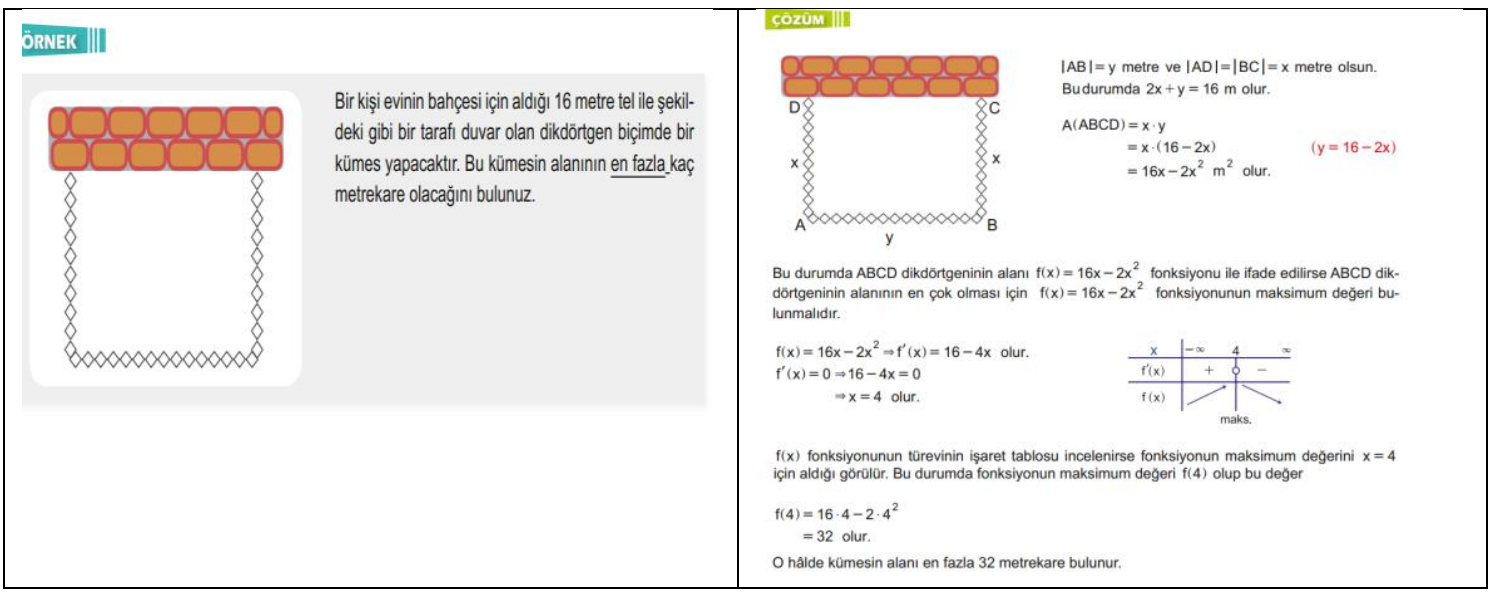

Şekil 8. Ders Kitabı-2'de kullanılan kenar uzunluğuna bağlı alan bağlamı (s. 276)

Şekil 8'de verilen örnek üzerinden ifade etmek gerekirse, $x$ ile gösterilen kenar uzunluğuna bağlı $\mathrm{A}(\mathrm{x})$ fonksiyonun denkleminin yanında, dinamik geometri yazılımları sayesinde bunun dinamik grafik çizimi ve tablo verileri ile birlikte kenar uzunluğunun anlık değişimlerinde alanın nasıl değiştiği gözlemlenebilir. Bunun ötesinde, burada alan fonksiyonunun türevinin anlamı yorumlandığında, kenar uzunluğunun her bir birim değişiminde alanın nasıl değiştiği (kesikli kovaryasyon) ya da kenar uzunluğundaki küçük bir miktar değişiminde bu değişimin kaç katı kadar miktarda alanın değişeceği (sürekli kovaryasyon, nispi büyüklük) gibi yorumlamalar öğrencilerin türevi farklı bağlamlarda anlamlandırmalarına büyük katkı sağlayabilir.

\section{SONUÇ, TARTIŞMA VE ÖNERİLER}

Literatür bölümünde ifade edildiği gibi, türev ve türevin değişim oranı yorumu ileri analiz konu ve kavramlarına temel teşkil etmektedir. Kullanım alanının geniş olması sebebiyle, türev kavramının doğru anlaşılması bireylerin matematik okuryazarlığı ve ileri matematik konularını anlamlandırmaları bakımından da önemlidir. Fakat literatür incelendiğinde türev kavramının anlamlandırılmasıyla ilgili öğretmen ve öğrenci zorlukları geçmişten günümüze birçok ülkede ortak bir sorun olarak karşımıza çıkmaktadır (örn. Berry ve Nyman, 2003; Bezuidenhout, 1998; Byerley ve Thompson, 2017; Gökçek ve Açıkyıldız, 2016; Herbert ve Pierce, 2011; Mkhatshwa ve Doerr, 2018). Nicel muhakeme bakış açısıyla türev kavramı, "iki nicelikteki değişimlerin çarpımsal kıyaslaması sonucunda elde edilen yeni bir nicelik" olarak tanımlanmakta ve bu kavramın doğru anlaşılması için farklı gerçek hayat bağlamlarında türev olarak tarif edilen niceliğin anlamlandırılmasının önemine işaret edilmektedir (Thompson, 1994; 2011). Bu çalışma kapsamında ilk olarak nicel muhakeme perspektifinden türev kavramının ne anlama geldiği teorik olarak incelenmiştir. Sonrasında, nicel muhakeme perspektifinden (i) bağlam çeşitliliği, (ii) birimlerin kullanımı ve yorumlanması, (iii) kovaryasyon fikri ve (iv) nispi büyüklük fikri olmak üzere dört temel prensip belirlenmiş 
ve bu prensipler doğrultusunda Türkiye'de hâlihazırda okutulan ders kitapları analiz edilmiştir.

İncelenen üç kitapta, türev konusunda çözümlü örnek, etkinlik ve değerlendirme soruları gibi içerikler için kullanılan gerçek hayat bağlamları incelediğinde kinematik (yol-zaman, hız-zaman) bağlamlarının daha sık kullanıldığı, ekonomi ve bağımsız değişkenin zaman olmadığı dinamik bağlamların daha nadiren kullanıldığı görülmektedir (bkz. Tablo 1). Hatta herhangi bir bağlamın kullanılmadığı cebirsel işlem gerektiren içeriğin daha yoğun olduğu da göze çarpmaktadır. Uzunluk-alan-hacim gibi bağlamların ise daha çok optimizasyon (türevin uygulamaları) kısmında kullanıldığı ve bu bağlamlarda türevin anlamı üzerine yorumlama yapılmadığı görülmektedir. Dolayısı ile türev kavramı ve değişim oranı yorumu genellikle kinematik bağlamıyla kısıtlı olarak verildiği söylenebilir. Bu durum sadece Türkiye'ye mahsus olmayıp, türev kavramının kinematik bağlamıyla kısıtlı öğretildiği, ders kitaplarının sadece kinematik bağlamına yer verdiği bulguları uluslararası birçok çalışma da ortaya konulmuştur (örn. Byerley ve Thompson, 2017; Jones, 2017; Mkhatshwa ve Doerr, 2018; Weber ve Dorko, 2014). Bu çalışma, Türkiye'de ortaöğretim düzeyi TTKB ders kitaplarında da benzer durumun olduğunu ortaya koymaktadır.

Birimlerin kullanımı bakımından incelendiğinde, her üç kitapta da birimler çoğunlukla yerinde kullanılmış olmakla birlikte derinlemesine yorumlama yapılmadığı görülmektedir. Yine literatür incelendiğinde, türev kavramı ile ilgili öğretmen ve öğrenci zorluklarının temeli olarak öğretim sürecinde ve ders kitaplarında kovaryasyon fikrinin yeterince vurgulanmadığı raporlanmaktadır (örn. Carlson vd., 2002; Thompson ve Carlson, 2017; Cooney vd., 2010; Castillo-Garsow, 2012; Byerley ve Thompson, 2017; Thompson, 1994). Bu çalışma kapsamında incelenen ders kitaplarında da kovaryasyon ve nispi büyüklük fikirlerinin hemen hemen hiç vurgulanmadığl görülmüştür. Kovaryasyon fikrini destekleyebilecek potansiyele sahip, bağımsız değişkenin zaman olmadığı, dinamik değişimlerin doğrudan gözlemlenebileceği bağlamalar görülmekte, fakat bu bağlamlar genellikle optimizasyon problemlerinde karşımıza çıkmaktadır. Optimizasyon problemlerinde ise türev kavramının anlamı üzerine bir yorumlama yapılmamakta, sadece işlemsel (prosedürel) olarak birinci türevi sıfıra eşitleyerek maksimum ve minimum nokta adaylarını belirlemeye yönelik uygulamalara yer verilmektedir. Daha önce de ifade edildiği gibi optimizasyon problemlerinde kullanılan bağlamlarda türevin anlamının yorumlanmaması büyük bir fırsatın heba edilmesi olarak görülebilir. Zira türev kavramının farklı bağlamlarda ne anlama geldiğinin yorumlanması her defasında değişim oranı yorumuna farklı bir kimlik ve anlam kazandırmaktadır. Örneğin, boşalan bir barajda zamana bağlı su miktarı fonksiyonunun türevi debi anlamına gelirken, zamana bağlı hız fonksiyonunda türev ivme anlamına, ürün miktarına bağlı maliyet fonksiyonunun türevi marjinal maliyet anlamına, suyla dolan bir depoda yüksekliğe bağlı hacim fonksiyonunun türevi ise arakesit alanı anlamına gelmektedir. Aslında bunların hepsi türevin değişim oranı yorumundan ibaret olsa da bağlama göre özel anlamlarının da olduğu bir gerçektir. İşte bu nedenle, öğrencilerin türevin farklı bağlamlarda değişim oranı yorumunu yaparak bu özel 
anlamların da farkında olmalarını sağlamak nicel muhakeme bakış açısıyla öğrencilere kazandırılması hedeflenen temel bilgi ve becerilerdir.

İncelenen kitapların her üçünde de türev kavramının nispi büyüklük fikrini içeren vurgulamaların yapılmaması önemli eksiklerden bir diğeridir. Türev kavramının nispi büyüklük olarak (bağımlı değişkendeki değişimin, bağımsız değişkende meydana gelen bir miktar değişimin kaç katı kadar olduğu) yorumlanması, türevin farklı gerçek hayat bağlamlarında bir oran olarak anlamlandırmak açısından önem taşımaktadır (Byerley ve Thompson, 2017). Çünkü literatür incelendiğinde türevin bir değişkende meydana gelen değişim miktarı olarak görülmesi öğrenciler de en yaygın ortaya çıkan kavram yanılgılarından birisidir (örn. Byerley ve Thompson, 2017; Mkhatshwa ve Doerr, 2018; Rowland ve Javanoski, 2004; Thompson, 1994). Türev kavramının nispi büyüklük olarak anlamlandırılmasını desteklemek için doğrusal yaklaşım uygulamalarına daha sık yer verilmelidir. Yine, birim zamanda alınan yol, bir birim daha ürün üretildiğinde ortaya çıkan maliyet gibi yorumlamalar doğrusal yaklaşım ile ilişkilendirilerek uygulanabilir. Tabi burada bağımsız değişkendeki değișimi bir birime sabitleyerek düşünmenin, öğrencilerde türevin bağımlı değişkende meydana gelen değişim miktarı olarak algılamasına sebep olabileceği ( $\frac{\Delta y}{\Delta x}$ oranında payda, yani $\Delta x=1$ olduğunda $\frac{\Delta y}{\Delta x}$ ile $\Delta y$ aynı nümerik değeri aldığından) unutulmamalıdır (Cooney vd., 2010; Mkhatshwa, 2018). Dolayısıyla, bir noktada türev değeri verilerek bunun kullanılan değişkenler açısından ne anlama geldiği, örneğin bağımsız değişken 0,0002 birim değiştiğinde bağımlı değişkenin ne kadar değişeceği veya fonksiyonun yeni değerinin ne olacağı gibi yorumlamalar türevin nispi büyüklük olarak anlamlandırılmasına katkı sağlayacaktır. Hatta, ekonomide kullanılan marjinal maliyet ve marjinal kar gibi yorumlamaların türev kavramında bağımsız değişkendeki sonsuz küçüklükteki değişim bakımından tartışılması öğrencilerin farklı bağlamlarda türev uygulamalarının matematiksel olarak sorunlu yönlerinin de farkına varmalarını sağlayacaktır (Mkhatshwa, 2018; Mkhatshwa ve Doerr, 2018).

Sonuç olarak, ders kitaplarında türev kavramının değişim oranı yorumu ele alınsa da bunun sadece kinematik bağlamıyla sınırlı kaldığı ve derinlemesine yorumlamaların yapılmadığı görülmektedir. Bağımsız değişkenin zaman olmadığı, dinamik ve eş zamanlı değişimi daha net ortaya koyabilecek ve dolayısıyla kovaryasyon fikrini desteklemeye yönelik uygulamalara daha fazla yer verilmelidir. İki değişkenin birlikte değişimini dinamik animasyon olarak göstermek öğrencilerin kovaryasyonel düşünme becelerine katkı sağlama potansiyeline sahiptir (Kertil, 2020). Dinamik geometri yazılımları ile hazırlanan teknoloji etkinlikleri de bunun için bir fırsat olarak görülmelidir. Ayrıca, nispi büyüklük fikri de yine farklı bağlamalarda kovaryasyon ve doğrusal yaklaşım uygulamalarıyla desteklenmelidir. 


\section{Kaynaklar}

Altun, M. H. (2018). Matematik 12. sinıf ders kitabı. Ankara: Tutku Yayıncllık.

Ärlebäck, J. B., Doerr, H. M. ve O'Neil, A. M. (2013). A modeling perspective on interpreting rates of change in context. Mathematical Thinking and Learning, 15(4), 314-336.

Ärlebäck, J. B. ve Doerr, H. M. (2018). Students' interpretations and reasoning about phenomena with negative rates of change throughout a model development sequence. ZDM-Mathematics Education, 50, 187-200.

Bektaşlı, B. ve Çakmakçı, G. (2011). Consistency of students' ideas about the concept of rate across different contexts. Education and Science, 36 (162), 273-287.

Berry, J. S. ve Nyman, M. A. (2003). Promoting students' graphical understanding of the calculus. The Journal of Mathematical Behavior, 22, 481-497.

Bezuidenhout, J. (1998). First year university students' understanding of rate of change. International Journal of Mathematical Education in Science and Technology, 29(3), 389-399.

Byerley, C. ve Thompson, P. (2017). Secondary mathematics teachers' meanings for measure, slope, and rate of change. The Journal of Mathematical Behavior, 48, 168193.

Byerley, C. (2019). Calculus students' fraction and measure schemes and implications for teaching rate of change functions conceptually. The Journal of Mathematical Behavior, 55, 100694.

Bingolbali, E. (2008). Türev kavramına ilişkin öğrenme zorlukları ve kavramsal anlama için öneriler. M. F. Özmantar, E. Bingolbali, \& H. Akkoç (Eds.), Matematiksel kavram yanılgıları ve çözüm önerileri (pp. 223-255). Ankara: Pegem A.

Bingolbali, E. \& Bingolbali, F. (2020). An examination of tasks in elementary school mathematics textbooks in terms of multiple outcomes and multiple solution methods. International Journal of Educational Studies in Mathematics, 7(4), 214235.

Carlson, M., Jacobs, S., Coe, E., Larsen, S. ve Hsu, E. (2002). Applying covariational reasoning while modeling dynamic events. Journal for Research in Mathematics Education, 33(5), 352-378.

Castillo-Garsow, C. (2012). Continuous quantitative reasoning. In R. L. Mayes, \& L. Hatfield (Eds.), Quantitative reasoning and mathematical modeling: A driver for STEM integrated education and teaching in context (pp. 55-73). Laramie: University of Wyoming Press.

Confrey, J. \& Smith, E. (1994). Exponential functions, rates of change, and the multiplicative unit. Educational Studies in Mathematics, 26(2/3), 134-165. 
Cooney, T. J., Beckman, S. ve Lloyd, G. M. (2010). Developing essential understanding of functions for teaching mathematics in grades 9-12. Reston, VA: National Council of Teachers of Mathematics.

de Almeida, L.M.W. \& da Silva, K.A.P. (2018). A semiotic interpretation of the derivative concept in a textbook. ZDM Mathematics Education 50, 881-892. https://doi.org/10.1007/s11858-018-0975-8

Doorman, L. M. ve Gravemeijer, K. P. E. (2009). Emergent modeling: discrete graphs to support the understanding of change and velocity. ZDM Mathematics Education 41(1-2), 199-211. https://doi.org/10.1007/s11858-008-0130-z

Ellis, A. B., Ozgur, Z., Kulow, T., Williams, C. C. ve Amidon, J. (2015). Quantifying exponential growth: Three conceptual shifts in coordinating multiplicative and additive growth. The Journal of Mathematical Behavior, 39, 135-155. doi:10.1016/j.jmathb.2015.06.004

Emin, A., Gerboğa, A., Güneş, G. \& Kayacıer, M. (2020). Matematik 12. sınıf ders kitabı. Ankara: MEB yayınları.

Gökçek, T. ve Açıkyıldız, G. (2016). Matematik öğretmeni adaylarının türev kavramıyla ilgili yaptıkları hatalar. Turkish Journal of Computer and Mathematics Education, $7(1), 112-141$.

Hawson, G. (2013). The development of mathematics textbooks: historical reflections from a personal perspective. ZDM Mathematics Education, 45, 647-658.

Herbert, S. ve Pierce, R. (2011). What is rate? Does context or representation matter? Mathematics Education Research Journal, 23(4), 455-477.

Herbert, S. ve Pierce, R. (2012). Revealing educationally critical aspects of rate. Educational Studies in Mathematics, 81(1), 85-101.

İncikabı, L. \& Tjoe, H. (2013). A comparative analysis of ratio and proportion problems in Turkish and the U.S. middle school mathematics textbooks. Ahi Evran Üniversitesi Kırşehir Eğitim Fakültesi Dergisi (KEFAD), 14(1), 1-15.

Jones, S. R. (2017). An exploratory study on student understandings of derivatives in real-world, non-kinematics contexts. The Journal of Mathematical Behavior, 45, 95110.

Kemancl, B., Büyükokutan, A., Çelik, S. \& Kemancı, Z. (2020). Fen lisesi 12. sinıf matematik ders kitabı. Ankara: MEB yayınları.

Kertil, M. (2014). Pre-service elementary mathematics teachers' understanding of derivative through a model development unit (Unpublished doctoral dissertation). Middle East Technical University, Graduate School of Natural and Applied Sciences, Ankara.

Kertil, M. (2020). Covariational reasoning of prospective mathematics teachers: How do dynamic animations affect? Turkish Journal of Computer and Mathematics Education, 11(2), 312-342. doi:10.16949/turkbilmat.652481. 
Kertil, M., Erbaş, A. K. ve ve Çetinkaya, B. (2017). İlköğretim matematik öğretmen adaylarının değişim oranı ile ilgili düşünme biçimlerinin bir modelleme etkinliği bağlamında incelenmesi. Turkish Journal of Computer and Mathematics Education, $8(1), 188-217$.

Kertil, M., Erbaş, A. K. ve Çetinkaya, B. (2019). Developing prospective teachers' covariational reasoning through a model development sequence. Mathematical Thinking and Learning, 21, 207-233.

Lobato, J., Hohensee, C., Rhodehamel, B. ve Diamond, J. (2012). Using student reasoning to inform the development of conceptual learning goals: The case of quadratic functions. Mathematical Thinking and Learning, 14(2), 85-119.

MEB (2018). Ortaöğretim Matematik Dersi (9-12. Sınıflar) Öğretim Programı. Ankara: Milli Eğitim Bakanlığı Yayınları.

Mkhatshwa, T. P. (2016). Business calculus students' reasoning about optimization problems: A study of quantitative reasoning in an economic context (Doctoral dissertation). New York, NY: Syracuse University.

Mkhatshwa, T. P. (2018). Business calculus students' interpretations of marginal change in economic contexts. In Hodges, T.E., Roy, G. J. ve Tyminski, A. M. (Eds.), Proceedings of the 40th Annual Meeting of the North American Chapter of the International Group for the Psychology of Mathematics Education (pp. 564-571). Greenville, SC: University of South Carolina \& Clemson University.

Mkhatshwa, T. ve Doerr, H. (2018). Undergraduate students' quantitative reasoning in economic contexts. Mathematical Thinking and Learning, 20(2), 142-161. https://doi.org/10.1080/10986065.2018.1442642

Park, J. (2016). Communicational approach to study textbook discourse on the derivative. Educational Studies in Mathematics, 91, 395-421. https://doi.org/10.1007/s10649-015-9655-6

Randahl, M. ve Grevholm, B. (2010). Learning opportunities in a classical calculus book. Nordic Studies in Mathematics Education, 15(2), 5-27.

Rowland, D. R. ve Jovanoski, Z. (2004). Student interpretation of the terms in first-order ordinary differential equations in modeling contexts. International Journal of Mathematical Education in Science and Technology, 35(4), 505-516.

Schmidt, W. H. (2012). Measuring content through textbooks: The cumulative effect of middle-school tracking. In G. Gueudet, B. Pepin, \& L. Trouche (Eds.), From text to 'lived' resources: Mathematics curriculum materials and teacher development (pp. 143-160). Dordrecht: Springer.

Schwartz, J. (1988). Intensive quantity and referent transforming arithmetic operations. In J. Hiebert \& M. Behr (Eds.), Number concepts and operations in the middle grades (pp. 41-52). Reston, VA: NCTM. 
Stroup, W. (2002). Understanding qualitative calculus: A structural synthesis of learning research. International Journal of Computers for Mathematical Learning, 7(2), 167215.

Teuscher, D. \& Reys, R. E. (2012). Rate of change: AP calculus students' understandings and misconceptions after completing different curricular paths. School Science and Mathematics, 112(6), 359-376. https://doi.org/10.1111/j.19498594.2012.00150.x

Thompson, P. W. (1994). Images of rate and operational understanding of the fundamental theorem of calculus. Educational Studies in Mathematics, 26, 229-274.

Thompson, P. W. (2011). Quantitative reasoning and mathematical modeling. In L. L. Hatfield, S. Chamberlain, \& S. Belbase (Eds.), New perspectives and directions for collaborative research in mathematics education (Vol. 1, pp. 33-57). Laramie, WY: University of Wyoming.

Thompson, P. W. ve Carlson, M. P. (2017). Variation, covariation, and functions: Foundational ways of thinking mathematically. In J. Cai (Ed.), Compendium for research in mathematics education (pp. 421-456). Reston, VA: National Council of Teachers of Mathematics.

Thompson, P. W., Hatfield, N. J., Yoon, H., Joshua, S. ve Byerley, C. (2017). Covariational reasoning among U.S. and South Korean secondary mathematics teachers. The Journal of Mathematical Behavior, 48, 95-111.

Weber, E. \& Dorko, A. (2014). Students' and experts' schemes for rate of change and its representations. The Journal of Mathematical Behavior, 34, 14-32.

Wilhelm, J. A. \& Confrey, J. (2003). Projecting rate of change in the context of motion onto the context of money. International Journal of Mathematical Education in Science and Technology, 34(6), 887-904. https://doi.org/10.1080/00207390310001606660

Yavuz, İ. \& Baştürk, S. (2011). Ders kitaplarında fonksiyon kavramı: Türkiye ve Fransa örneği. Kastamonu Eğitim Dergisi, 19(1), 199-220.

Yıldırım, A. \& Şimşek, H. (2011). Sosyal bilimlerde nitel araştırma. Ankara: Seçkin Yayıncılık.

Zandieh, M. (2000). A theoretical framework for analyzing students' understanding of the concept of derivative. In E. Dubinsky, A. H. Schoenfeld, \& J. Kaput (Ed.), Research in collegiate mathematics education (vol. IV, pp. 103-127). Providence, RI: American Mathematical Society.

Zandieh, M. J. ve Knapp, J. (2006). Exploring the role of metonymy in mathematical understanding and reasoning: The concept of derivative as an example. The Journal of Mathematical Behavior, 25(1), 1-17. https://doi.org/10.1016/j.jmathb.2005.11.002 
“Değişim Oranı Olarak Türevin Kavramsal Analizi ve Matematik Ders Kitaplarının Analizi" başlıklı çalışmanın yazım sürecinde bilimsel, etik ve atıf kurallarına uyulmuş; toplanan veriler üzerinde herhangi bir tahrifat yapılmadığı bu çalışmanın yazarları tarafından taahhüt edilmiştir. Karşılaşılabilecek tüm etik ihlallerden "Sakarya University Journal of Education Dergisi ve Editörü"nün sorumlu olmadığı, tüm sorumluluğun yazarlarına ait olduğu ve çalışmanın başka bir akademik yayın ortamına değerlendirilmek üzere gönderilmediği yazar tarafından beyan edilmiştir.

\section{Araştırmacıların Makaleye Katkı Oranı Beyanı:}

1. yazar katkı oranı: $\% 100$

Çıkar Çatışması Beyanı:

Yok.

Finansal Destek veya Teşekkür Beyanı

$\mathrm{Bu}$ çalıșma için herhangi bir kurumdan finansal destek alınmamıștır. 